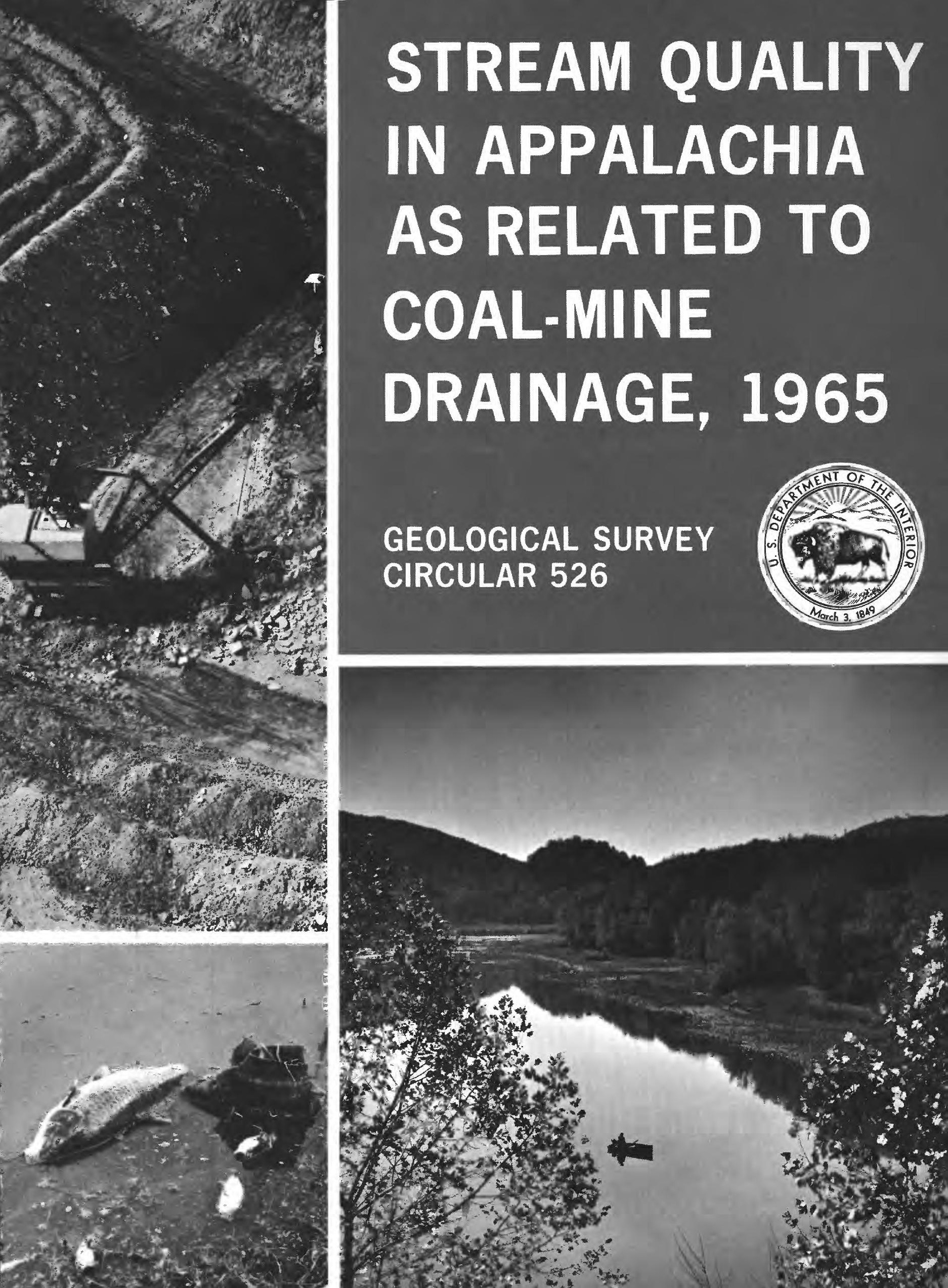




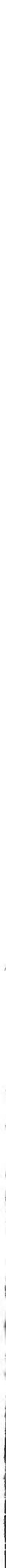




\title{
Stream Quality in Appalachia as Related to Coal-Mine Drainage, 1965
}

\author{
By J. E. Biesecker and J. R. George
}

x

Geological Survey Circular 526 
United States Department of the Interior STEWART L. UDALL, Secretary

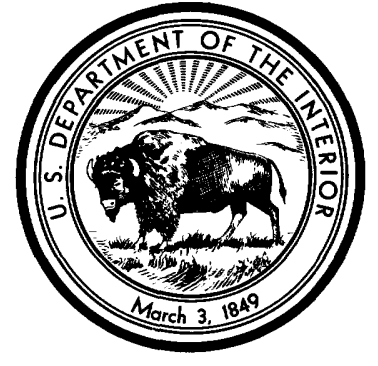

Geological Survey

William T. Pecora, Director

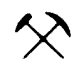




\section{CONTENTS}

Page

Definition of terms .......... IV

Abstract

Introduction ................. 1

Purpose and scope ................ 1

Acknowledgments .................. 2

Coal mining and mine water........ 2

Mine drainage and stream quality.... 5

Stream-quality observations ......... 6

The field reconnaissance ............ 6
Stream-quality observations-Continued

Basic quality of streams in Appalachia_._._................. 7

Effects of mine drainage on stream quality ................... 8

Neutralization of acid streams ....... 11

Conclusions and recommendations...... 11

References .......................... 13

Basic data .......................... 15

\section{ILLUSTRATIONS}

Cover photographs. Upper left, Strip mine in Appalachia (courtesy of Bureau of Mines, U.S. Department of the Interior). Lower left, Large carp and catfish, part of a scene of dead fish along an Appalachian river (courtesy of Johnny Nicklas, Chief Photographer, Pennsylvania Fish Commission). Lower right, View of Juniata River, Pa. (courtesy of Grant Heilman, Lititz, Pa.).

Plate 1. Map showing quality of streams in Appalachia as related to mine drainage..-_In pocket

Figure 1. Map showing location of coal deposits ...... 2

2. Graph showing comparison of coal production to miles of affected streams $\ldots . . .-5$

3. Map showing areas in the Appalachian coal region where streams affected by mine drainage contained relatively high concentrations of bicarbonate, May 1965

4-6. Graphs showing-

4. Effect of coal-mine drainage on sulfate content from northern to southern Appalachia, May 1965

5. Effect of mine drainage on the hardness of water, May 1965

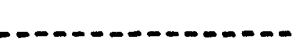

6. Changes in composition of a mine-polluted stream during neutralization, Ohio River basin, May 1965

\section{TABLES}

Table 1. Total coal production in Appalachia, 1923-63

2. Type of mining in Appalachia, 1963

3. Chemical composition of typical mine waters in Appalachia . . . . . .

4. Use limitations of water-quality parameters typical of coal-mine drainage...... 6

5. Effect of mine drainage on the potential use of streams draining the coal region of Appalachia, May 1965 ..........

6. Field determinations and laboratory analyses for stream samples collected in May 1965 


\section{DEFINITION OF TERMS}

Acidity.-The capacity of a water for neutralizing a basic solution. Acidity, as used in this report, is caused primarily by the presence of hydrogen ions produced by hydrolysis of the salts of strong acids and weak bases.

Alkalinity. - The capacity of a water for neutralizing an acid solution. Alkalinity in natural water is caused primarily by the presence of carbonates and bicarbonates.

Dissolved solids. - Consist mainly of the dissolved mineral constituents in water and is represented by the residue that remains after evaporation and drying at a temperature of $180^{\circ} \mathrm{C}$.

Hardness.- A property of water which causes an increase in the amount of soap that is needed to produce foam or lather. Hardness is produced almost completely by the presence of calcium and magnesium salts in solution. Carbonate hardness is represented by the carbonate and bicarbonate salts of calcium and magnesium. Noncarbonate hardness is represented by all other salts of calcium and magnesium. Hardness is expressed conventionally in terms of an equivalent quantity of calcium carbonate. The following scale may assist the reader in appraising hardness:

Degree of hardness

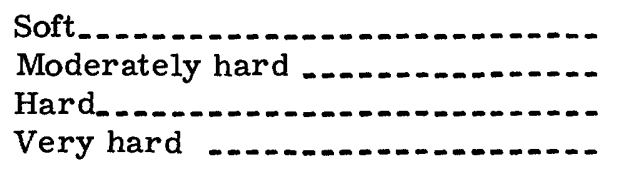

Hardness range (ppm)

$$
\begin{gathered}
0-60 \\
61-120 \\
121-180 \\
>180
\end{gathered}
$$

Parts per million (ppm).-A unit for expressing the concentration of chemical constituents by weight, for example, as grams of constituents per million grams of solution.

pH.- A measure of the hydrogen-ion concentration of a solution. A pH unit is expressed as the negative $\log _{10}$ of the hydrogen-ion concentration. The $\mathrm{pH}$ of pure water is 7.0, acid water has a smaller $\mathrm{pH}$ and alkaline water a larger $\mathrm{pH}$.

Specific conductance.- A measure of the ability of a water to conduct an electrical current. It is expressed in micromhos at $25^{\circ} \mathrm{C}$. Pure water has a very small electrical conductance, but the conductance increases with increasing concentration of dissolved minerals. 


\title{
Stream Quality in Appalachia as Related to Coal-Mine Drainage, 1965
}

\author{
By J. E. Biesecker and J. R. George
}

\section{ABSTRACT}

A stream-quality reconnaissance at 318 locations in May 1965 offered the first opportunity for a contemporaneous regional collection and appraisal of water-quality data in Appalachia. The results provide a means of regional comparison of the influence of coal-mine drainage on stream quality at approximately median streamflow. The results disclose that the chemical quality of the water at nearly 200 sites did not meet recommended drinking-water standards. At many of these sites, inferior quality was caused by excessive concentrations of solutes commonly associated with coalmine waters.

\begin{abstract}
Water-quality damage from mine drainage is particularly severe in the more heavily mined northern one-third of the region where high sulfate content, free mineral acidity, and low $\mathrm{pH}$ are typical of most affected streams. A deficiency in natural stream alkalinity in this part of the coal region contributes greatly to the massive effect of mine drainage upon stream quality. However, data collected from streams affected by mine drainage along the west edge of this part of the coal field suggest extensive neutralization of mine water. In southern Appalachia coal-mine drainage had less influence on stream quality than in northern Appalachia. Fewer streams in this area were influenced by mine drainage, and the magnitude of stream damage for affected streams was less than in northern Appalachia.
\end{abstract}

\section{INTRODUCTION}

Extensive coal mining in the Appalachian region for several decades has measurably influenced stream quality throughout the area. The deterioration of streams that receive coal-mine drainage has seriously limited the industrial and domestic uses of these waters. This undesirable alteration of natural stream quality has placed economic restrictions on many downstream water users.

Highly detailed individual studies and some broad statewide studies of the mine-drainage problem have varied greatly in technical approach as well as analytical methodology. However, most attempts to understand the problem and to define the extent of streamquality damage were not designed to measure the relative significance of mine drainage on the water resources of the entire region. Public awareness of the problem balanced by technical concern over water pollution warrants abroad look at water pollution from coal-mine drainage throughout the entire 11-State area known as Appalachia (see subsection on "Coal mining and mine water" for definition of boundaries).

\section{PURPOSE AND SCOPE}

To evaluate the significance of this waterpollution problem in Appalachia, to update stream-quality data, and to provide technical continuity in collection of these data, the Geological Survey acquired extensive streamflow and water-quality information in May 1965. This report summarizes the results of the first major regional reconnaissance, describes somebasic water-quality characteristics of streams in the area, discusses the observed effects of mine drainage upon stream quality, and delineates areas where stream pollution by coal-mine drainage was most severe during the period of study.

The authors wish to make it clear that this report may present only limited new evidence of stream pollution by mine drainage to those interested in any specific part of Appalachia. The reconnaissance study is intended primarily to offer a means of assessing the magnitude of this water problem throughout the entire region. This report provides a foundation of data to guide future regional studies. It also should assist in the selection of areas that require special, more detailed attention. 


\section{ACKNOWLEDGMENTS}

The authors are grateful to the many Water Resources Division offices which participated in the collection and appraisal of data presented in this report. We also wish to express thanks to the water resources agencies of the States in the Appalachia region for their cooperative support.

\section{COAL MINING AND MINE WATER}

The Appalachia region, as defined in Public Law 89-4 (1965), extends over parts of an
11-State area from Pennsylvania to Alabama (fig. 1). A small area in New York was added to Appalachia after enactment of Public Law 89-4. However, this report covers only that part of Appalachia south of the New YorkPennsylvania boundary. Coal deposits occur in approximately 50,000 square miles of the region and are in 9 of the 11 States. In many areas of Appalachia, coal has been intensively mined for more than 100 years. Records of production in some of these areas are available since post-Civil War years. Table 1 shows the amount of coal mined in Appalachia for the period 1923-63. It is

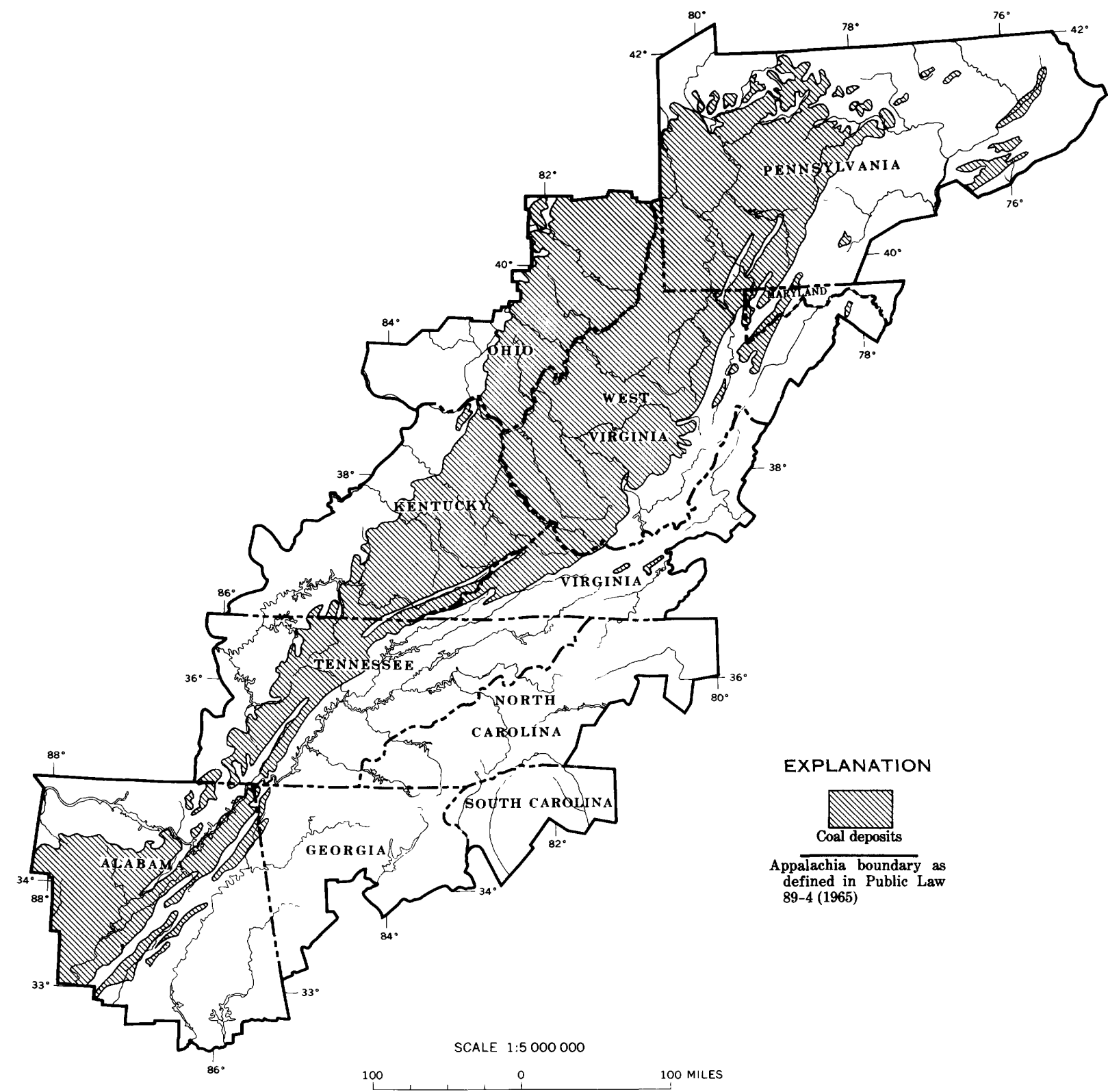

Figure 1. -Location of coal deposits. (From Trumbull, 1960.) 
Table 1.-Total coal production in Appalachia, 1923-63

\begin{tabular}{l|r|r}
\hline State & $\begin{array}{r}\text { Total coal pro- } \\
\text { duced, in thou- } \\
\text { sands of tons }\end{array}$ & $\begin{array}{c}\text { Per- } \\
\text { cent } \\
\text { of } \\
\text { total }\end{array}$ \\
\hline Alabama & 579,000 & 3.7 \\
Georgia & 1,000 & .0 \\
Kentucky- & $1,703,700$ & 10.8 \\
Maryland & 61,600 & .4 \\
Ohio.- & $1,097,200$ & 6.9 \\
Pennsylvania & $6,294,400$ & 39.7 \\
Tennessee & 230,700 & 1.4 \\
Virginia & 689,700 & 4.4 \\
West Virginia & $5,180,900$ & 32.7 \\
\hline
\end{tabular}

${ }^{1}$ U.S. Bureau of Mines (1963).

noteworthy that 72 percent of the coal was mined in two northern States-Pennsylvania and West Virginia. Kentucky, Ohio, Virginia, and Alabama also produced significant amounts.

The two principal methods of mining coal, underground mining and strip mining, produce vastly different hydrologic environments. The method used probably affects acid production. Many underground mines are below the zone of saturation, 1 so there is continual contact between sulfuritic material and water-a condition resulting generally in continual production of acid. Many strip mines are above the zone of saturation. This means that the pyritic material is in contact with water only during periods of excessive precipitation and mine drainage is thereby limited.

Underground mining has produced most of the coal in Appalachia. However, recent data reflect a major trend to produce coal by strip mining. Since 1940 the amount of coal produced in the United States by strip mining has increased from 9 to 34 percent U.S. Bureau Mines, 1963). In 1963 strip mining outproduced other methods of mining in Ohio and Maryland (table 2).

While the quantitative significance of various types of coal mining upon water pollution is not known, the problem, process, and products of mine drainage are similar for all types of mining. The problem begins with the

\footnotetext{
${ }^{1}$ The zone in which the rocks are saturated with water under hydrostatic pressure.
}

physical process of unearthing coal which exposes pyritic materials $\left(\mathrm{FeS}_{2}\right)$, commonly associated with coals, to water and air. Braley (1954), Krickovic (1965), and Stumm (1965) state that pyrite reacts with oxygen and water to form ferrous sulfate $\left(\mathrm{FeSO}_{4}\right)$ and sulfuric acid $\left(\mathrm{H}_{2} \mathrm{SO}_{4}\right)$. These chemical processes, whether within mines or waste piles, usually increase the concentrations of certain dissolved solids in the mine water. These index parameters include iron, sulfate, noncarbonate hardness, and total dissolved solids. Free mineral acidity, low $\mathrm{pH}$ values, and excessive concentrations of manganese and aluminum also are common characteristics of coal-mine waters. The sulfate in the reaction products makes an excellent indicator of mine-drainage pollution. Available data suggest that the chemical composition of mine waters throughout Appalachia is remarkably similar (table 3 ).

The concentration and composition of mine water, however, may be affected measurably by the presence of soluble rock minerals including calcium carbonate $\left(\mathrm{CaCO}_{3}\right)$, which in sufficient quantities neutralizes mine acid. This process increases the total hardness through the addition of calcium and magnesium, and can increase carbonate hardness when neutralization raises the $\mathrm{pH}$ above 4.5. Even when partial neutralization occurs, mine waters lose some free mineral acidity. Iron and aluminum precipitate at the higher $\mathrm{pH}$ produced by neutralization.

The significance of microorganisms in acid formation is discussed by Braley (1954). Braley states that the high acidity of many mine effluents in the bituminous coal region

Table 2.-Type of mining in Appalachia, $1963^{1}$

\begin{tabular}{|c|c|c|c|}
\hline \multirow[b]{2}{*}{ State } & \multicolumn{3}{|c|}{ Percent of total production } \\
\hline & $\begin{array}{l}\text { Under- } \\
\text { ground }\end{array}$ & $\begin{array}{l}\text { Strip } \\
\text { mining }\end{array}$ & $\begin{array}{c}\text { River } \\
\text { dredging }\end{array}$ \\
\hline Alabama & 77.4 & 22,6 & $-\cdots$ \\
\hline Georgia & 100.0 & & - \\
\hline Kentucky- & 66.7 & 33.3 & -- \\
\hline Maryland & 36.6 & 63.4 & $\ldots$ \\
\hline Ohio - & 33.7 & 66.3 & $---\ldots-n$ \\
\hline Pennsylvani & 59.9 & 35.6 & 4.5 \\
\hline Tennessee & 59.3 & 40.7 & \\
\hline Virginia -- & 92.5 & 7.5 & $\ldots$ \\
\hline West Virgini & 94.4 & 5.6 & \\
\hline
\end{tabular}

${ }^{1}$ U.S. Bureau of Mines (1963). 


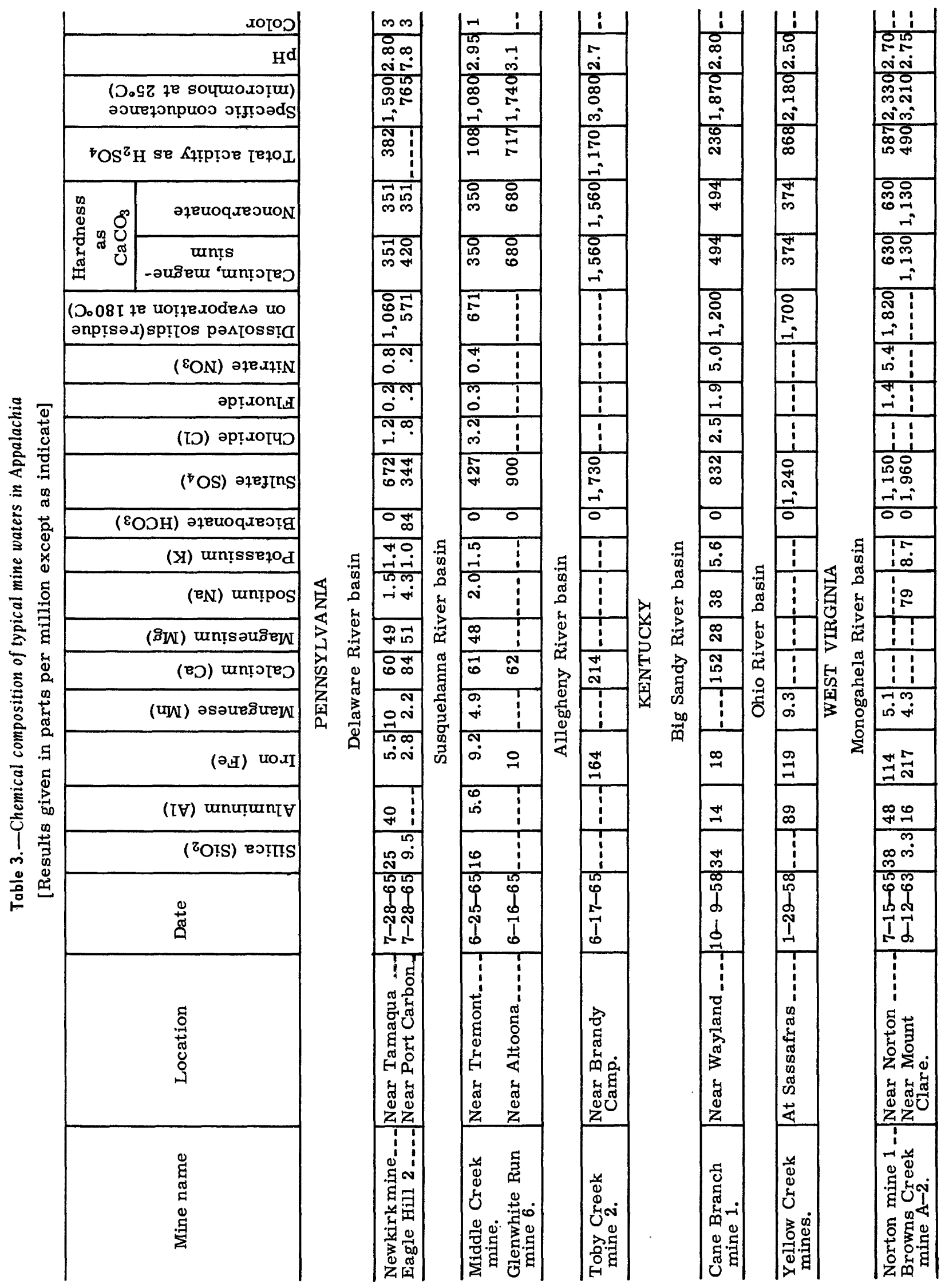


may be attributed, in part, to the action of certain bacteria on the pyritic constituents associated with coal.

Some authorities believe that acid cannot be produced in mines without air. Whether the acid-forming reaction involves atmospheric or dissolved oxygen is discussed by Barnes and Clarke (1964). They suggest that acid can be formed merely by dissolving pyritic materials in water.

\section{MINE DRAINAGE AND STREAM QUALITY}

The delivery of mine water to the surface drainage system is a critical factor in controlling the extent of stream pollution by coal-mine drainage. Relatively continuous delivery of water to a stream from active and abandoned coal mines creates continuous pollution of the stream. This type of streamquality damage is of great concern to industrial and domestic users who must maintain extensive treatment facilities to obtain a usable supply of water.

Occasional flushing of mines by excessive precipitation produces temporary, but often more dramatic, stream damage. Mine flushing delivers a large volume of water to a stream for a short time. When this mine effluent is carried downstream to points that normally are not affected by critical levels of pollutants, a fish kill may occur. The West Branch Susquehanna River in Pennsylvania, for example, experienced 20 major fish kills between 1948-62 (Corps of Engineers, 1962) because of the downstream transport of mine effluents by highly localized rains in the mining region.

The cumulative influence of both continuous and occasional stream pollution on fish habitat has been considered by the U.S. Bureau of Sport Fisheries and Wildlife (Kinney, 1964). Kinney reports that Pennsylvania and West Virginia contain over two-thirds of the stream mileage that is adversely affected by coal-mine drainage in Appalachia. There is a striking relationship between Kinney's data and coal production by each State in Appalachia (fig. 2).

Although both continuous mine drainage and mine flushouts are of great public concern, this broad reconnaissance study defines only a part of the continuous effects. In particular, the May field studies measured the in-

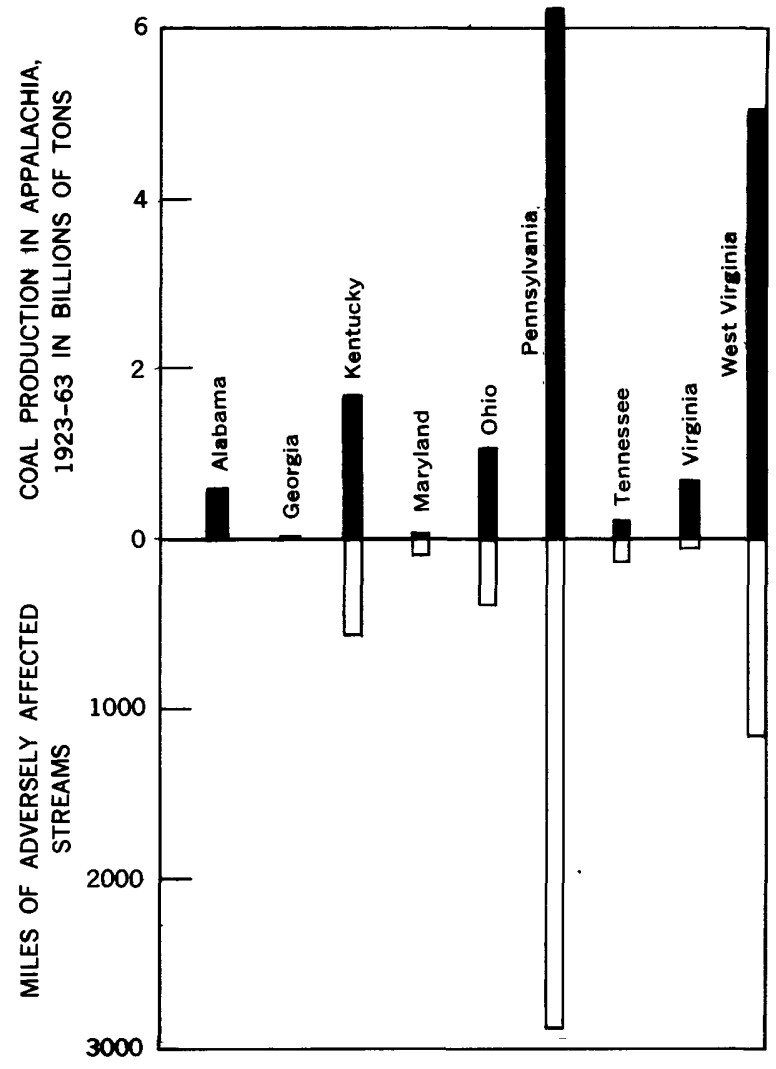

Figure 2. - Comparison of coal production (data from U. S. Bureau of Mines, 1964) to miles of affected streams (data from U.S. Dept. Int., Div, of Fishery Management Services, E.C. Kinney, 1964).

fluence of mine drainage on stream quality during near-median flow conditions when streams contained fairly dilute waters. Most continuous mine-drainage pollution problems observed in May should be more serious during the June to November low-flow period when stream waters normally are more concentrated.

Wherever stream-water quality is affected seriously by coal-mine drainage, many economic limitations are placed on the value of that water for recreational, industrial, and municipal uses. An abundance of mine-drainage constituents increases water-treatment costs and necessitates more frequent replacement of water-treatment facilities. River structures and navigation equipment often need special protection from corrosion by mine drainage. Deposits of sediment create an unattractive environment and render streams and lakes that receive mine discharge unfit for fishing, swimming, and other recreational uses.

Table 4 summarizes common water-use limitations of mine water. These include 
Table 4.-Use limitations of water-quality parameters typical of coal-mine drainage

\begin{tabular}{|c|c|c|c|c|c|c|c|c|}
\hline \multirow[b]{2}{*}{ Constituent } & \multirow{2}{*}{$\begin{array}{l}\text { Objectionable } \\
\text { features of } \\
\text { excessive } \\
\text { concentration }\end{array}$} & \multicolumn{7}{|c|}{ Recommended limiting concentration for indicated use $(\mathrm{ppm})^{1}$} \\
\hline & & $\begin{array}{l}\text { Public } \\
\text { water } \\
\text { supply } 2\end{array}$ & $\begin{array}{l}\text { Cooling } \\
\text { water }\end{array}$ & $\begin{array}{l}\text { Food } \\
\text { proces- } \\
\text { sing }\end{array}$ & $\begin{array}{l}\text { Pulp and } \\
\text { paper } \\
\text { making }\end{array}$ & $\begin{array}{c}\text { Plastics } \\
\text { manu- } \\
\text { facturing }\end{array}$ & Boilers & $\begin{array}{c}\text { Textile } \\
\text { manu- } \\
\text { facturing }\end{array}$ \\
\hline Sulfate -.- & $\begin{array}{l}\text { Diuretic effect, bitter } \\
\text { taste. }\end{array}$ & 250 & $-\cdots$ & $20-250$ & & & & 100 \\
\hline $\begin{array}{l}\text { Hardness as } \\
\mathrm{CaCO}_{3 *}\end{array}$ & $\begin{array}{l}\text { Boiler scale, produces } \\
\text { insoluble "curd" when } \\
\text { it reacts with soap. }\end{array}$ & & 50 & $10-400$ & $100-200$ & & $2-80$ & $0-50$ \\
\hline $\begin{array}{l}\text { Dissolved } \\
\text { solids. }\end{array}$ & $\begin{array}{l}\text { Diuretic effect, } \\
\text { unpleasant taste. }\end{array}$ & 500 & $-\cdots-\cdots$ & 850 & $200-500$ & 200 & $50-3,000$ & \\
\hline Iron & $\begin{array}{l}\text { Unpleasant taste, } \\
\text { stains porcelain and } \\
\text { linen. }\end{array}$ & .3 & .5 & 2 & $.1-1.0$ & & & 1.0 \\
\hline Manganese & $\begin{array}{l}\text { Unpleasant taste, } \\
\text { stains porcelain and } \\
\text { linen. }\end{array}$ & .05 & $.2-0.5$ & .2 & $.05-.5$ & .02 & & $.1-1.0$ \\
\hline Aluminum-- & Boiler scale. & & & & $10-100$ & & $\begin{array}{l}0-3 \\
0-10\end{array}$ & $-1-25$ \\
\hline $\begin{array}{l}\text { Suspended } \\
\text { solids. }{ }^{3} \\
\text { pH }^{4}\end{array}$ & $\begin{array}{l}\text { Clogs treatment fa- } \\
\text { cilities and water } \\
\text { courses. } \\
\text { Increases corro- } \\
\text { siveness. }\end{array}$ & 5 & 50 & $1-10$ & $10-100$ & & $8.0-9.6$ & $.3-25$ \\
\hline
\end{tabular}

${ }^{1}$ California Water Quality Control Board (1963).

${ }^{2}$ U.S. Public Health Service (1962).

${ }^{3}$ Turbidity, as silica, in parts per million.

${ }^{4}$ Value not to be less than limits shown.

unpleasant taste, staining, increased corrosiveness, formation of insoluble precipitates, and unpleasant diuretic effects and are caused by excessive concentrations of the mine-drainage index parameters.

\section{STREAM-QUALITY OBSERVATIONS}

\section{THE FIELD RECONNAISSANCE}

Available geologic, hydrologic, and coalmining data were used to select sampling sites (pl. 1) for the field reconnaissance. Because broad definition was a primary goal, many water-quality measurements in the 11State region were made for streams draining an area greater than 100 square miles. In areas of coal mining, sampling sites were selected for streams known or suspected to be influenced by mine drainage, so that the relative stream quality could be assessed. Several additional sites were selected to represent the water quality of streams not affected by mine drainage.
The field reconnaissance in the late spring of 1965 was intended to define general water quality for near-median streamflow conditions. Unregulated streamflow during the study was in the 45-65 percentile range and provided comparative data on the influence of mine drainage on streams in the entire region. Streamflow was generally steady and, therefore, water-quality results were not complicated by the effects of direct runoff from rains. Consequently, most of the analyses provide areawide data on near-average water quality.

During the intensive 9-day study period in May 1965, 11 two-man teams of hydrologists and chemists visted 318 stream sites from northeastern Pennsylvania to central Alabama, an area of more than 160,000 square miles. Field measurements included water discharge, $\mathrm{pH}$, specific conductance, water temperature, dissolved-oxygen concentration, and acidity. Water samples for more detailed analyses were also collected for 
delivery to U.S. Geological Survey laboratories in the region.

\section{BASIC QUALITY OF STREAMS IN APPALACHIA}

Streams in the coal region that are unaffected by mine drainage are of excellent quality. These streams contain very dilute alkaline water, with calcium and bicarbonate the dominant dissolved constituents. During the study period, the bicarbonate content of unpolluted streams in the coal-mining region generally was less than $50 \mathrm{ppm}$. Unaffected streams adjacent to the coal region contained bicarbonate concentrations from $50 \mathrm{ppm}$ to more than $200 \mathrm{ppm}$. Plate 1 delineates zones of relatively low and high concentrations of bicarbonate for streams within Appalachia. It is noteworthy that the central zone of low bicarbonate water generally coincides with the coal-field area.

The alkalinity of streams in the southeast edge of Appalachia was generally lower than that observed for other streams within the region. Here streams draining the crystalline-rock terrain of the Piedmont Province contain among the lowest solute content of streams in the Eastern United States (Rainwater, 1962).

Unusually low concentrations of bicarbonate for unaffected streams in the coal-mining region demonstrate the relative inability of most of these streams to neutralize acidmine water which enters the drainage system. When acid drainage from coal mines reacts with the low natural alkalinity of most streams in the coal region, the result is a large number of seriously affected streams carrying free mineral acidity.

While the May 1965 reconnaissance suggests that unaffected streams in the coal region contain relatively little neutralizing capacity, the bicarbonate alkalinity in some streams affected by mine drainage in parts of Pennsylvania, Ohio, West Virginia, Kentucky, and Virginia, indicates that extensive neutralization takes place within the coal region. Figure 3 illustrates a general area in the coal region where affected streams contain high concentrations $(50-200 \mathrm{ppm})$ of bicarbonate. These high alkalinities may be produced by neutralization from small, highly alkaline tributaries that were not sampled during this reconnaissance. Neutralization also may occur in the mines by contact of water with adjacent calcareous rocks (or by mixture of alkaline water associated with these strata). Scattered evidence of the existence of alkaline mine waters add credibility to the second choice, but it may be a combination of these conditions that produces generally high stream alkalinity in the area noted in figure 3.

Hardness is another water-quality index parameter in which major changes usually occur when mine waters are added to natural streamflow. The ranges in concentrations, zonal boundaries, and related criteria used to describe alkalinity of both unaffected and affected streams are similar for total-hardness data collected during the reconnaissance. Where mine drainage has not influenced stream quality in the coal region, total hardness was nearly always less than 50 ppm. In the areas immediately adjacent to the coal region, total hardness ranged from $50 \mathrm{ppm}$ to $300 \mathrm{ppm}$ or more. Again, streams draining the Piedmont province of southeastern Appalachia were most dilute, the hardness values ranging generally from 10 to 20 ppm.

Salty water brought to the earth's surface while developing oil and gas wells often affects stream quality. The May 1965 data indicate that only a few major streams in Ohio, Kentucky, and Pennsylvania contained concentrations of chlorides in excess of 100 ppm, and the concentrations exceeded U.S. Public Health Service (1962) "Drinking Water Standards" of $250 \mathrm{ppm}$ at only two sites. The chloride data indicate that although some brine pollution does exist in Appalachia, it is not a major problem on large streams during median flow.

The nitrate and phosphate content of stream water is considered a secondary indicator of pollution from untreated or treated domestic wastes as well as from some industrial wastes. In Appalachia, observed concentrations of nitrates and phosphates were low during the May 1965 reconnaissance. Concentrations of both constituents were well below recommended limits for public water supplies and also were acceptable for most industrial uses of water. The lack of these constituents in water, in fact, suggests a deficiency of some key nutrients that fertilize aquatic plants. This deficiency may provide a poorer environment for many types of aquatic insects and fish which, in turn, can 
exert some limitation on recreational development of the water.

Dissolved-oxygen concentration may also serve as an indicator of pollution by domestic and industrial waste. Although observed dissolved-oxygen values represent only an instantaneous evaluation of a complex and dynamic system of stream deoxygenation and reaeration, data collected during the reconnaissance offer means for a limited appraisal of stream conditions. In Appalachia, most observed dissolved-oxygen concentrations were above the suggested value of $5.0 \mathrm{ppm}$ (California Water Quality Control Board, 1963, p. 181), necessary for a favorable environment for fish and other aquatic life. The dissolved-oxygen concentration was less than $5.0 \mathrm{ppm}$ at only 10 of 318 locations.

\section{EFFECTS OF MINE DRAINAGE ON STREAM QUALITY}

The presence of free mineral acidity in a stream is the most serious evidence of water-quality damage by mine drainage. The May 1965 data clearly demonstrate that mine

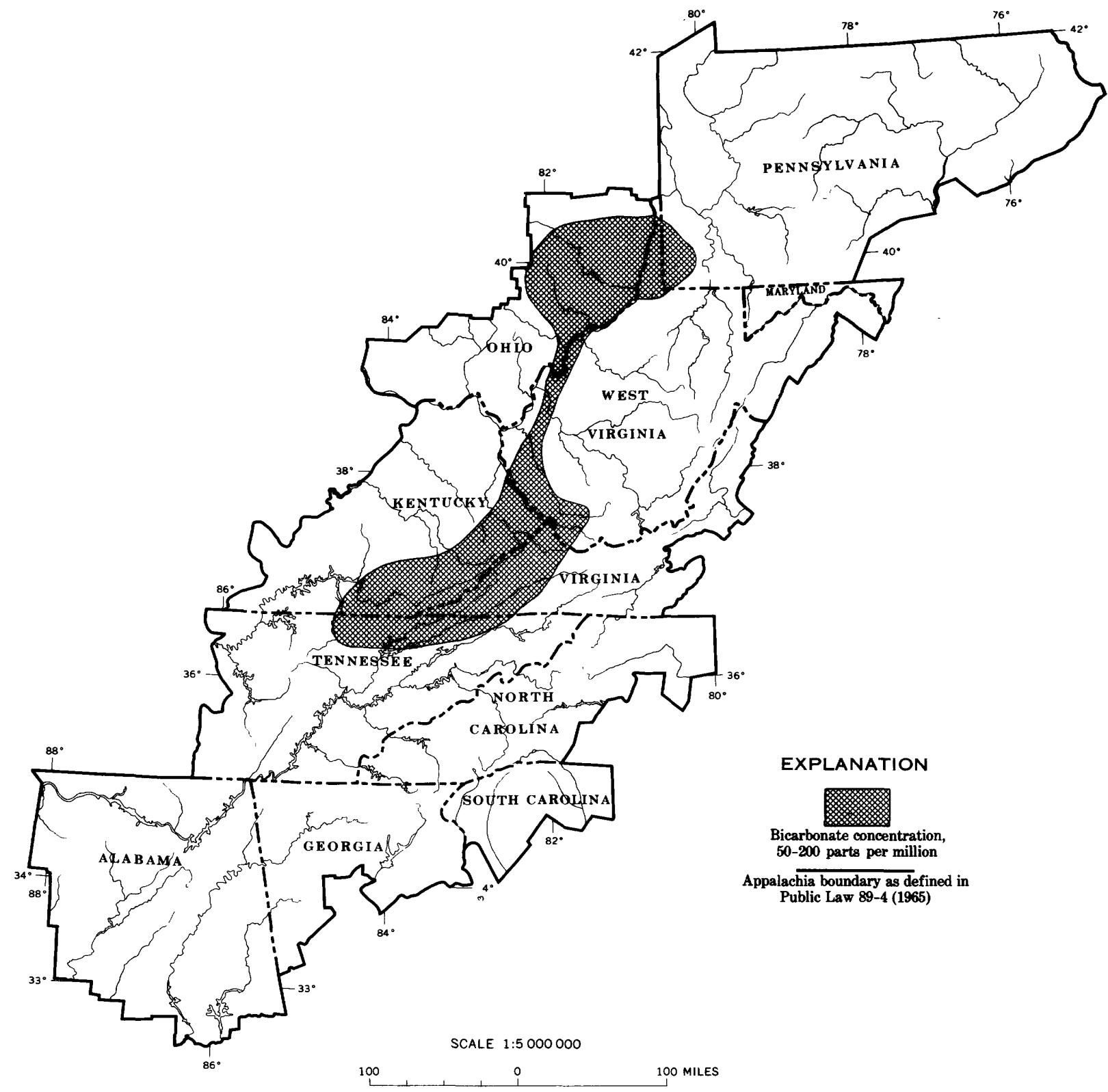

Figure 3. - Areas in the Appalachian coal region where streams affected by mine drainage contained relatively high(50-200 ppm) concentrations of bicarbonate, May 1965. 
drainage damages the chemical quality of streams more severely in the northern onethird of Appalachia than in the rest of Appalachia. (See pl. 1.) Free mineral acidity occurs in rivers as large as West Branch Susquehanna River, Kiskiminetas River, Casselman River, North Branch Potomac River, Monongahela River, and Raccoon Creek.

The abundance of acid mine waters in northern Appalachia may be due to several factors or to a combination of these factors. There is more coal mined in the north than in the south. This implies more extensive exposure of sulfuritic material to an acidproducing environment. Also, the amount of sulfuritic material exposed for each ton of coal mined in the north may be greater than in the south.

Further evidence of the abundance of acid water in northern Appalachia is shown on plate 1 as daily loads of sulfuric acid that were measured during the study period. Yearly acid loads at several locations are reported in U.S. Geological Survey Hydrologic Investigations Atlas HA-198 (Schneider and others, 1965). The May 1965 data illustrate the immense magnitude of the minedrainage problem in the West Branch Susquehanna River, Monongahela River, and Kiskiminetas River basins where the loads of acid per square mile are greater than those of other major basins in Appalachia.

The key index solute, sulfate, is used in this report to describe the influence of mine drainage on stream quality during median flow. Since observed concentrations of sulfate for unaffected streams draining the coal region were low (less than $20 \mathrm{ppm}$ ) during the study period, concentrations of sulfate greater than $20 \mathrm{ppm}$ are used to describe the measured effect of mine drainage on stream quality (pl. 1). The chemical quality of most major tributaries of the Susquehanna and Ohio Rivers that drain the Appalachian coal fields is affected to some extent by mine drainage. In the northern one-half of the coal region, only a few streams draining an unmined part of the Kanawha River basin are not influenced by mine drainage using sulfate concentration as an indicator of mine drainage. Farther south in parts of Tennessee, Georgia, and Alabama, scattered mining has little effect on the chemical quality of major streams in the area during median flow.
Figure 4 shows the north to south trend of sulfate content for streams affected by mine drainage. The median concentration of sulfate for affected streams in Pennsylvania and Ohio is $160 \mathrm{ppm}$, but only $45 \mathrm{ppm}$ for streams in Tennessee and Alabama. This decrease in sulfate concentration provides further evidence of less intense mine-drainage problems in southern Appalachia.

The effect of mine drainage on the hardness of water is shown in figure 5 . Note the greater percentage of samples in the hard and very hard class for mine-polluted waters. Median hardness was $130 \mathrm{ppm}$ for affected sites, and only $30 \mathrm{ppm}$ for unaffected sites.

With U.S. Public Health Service (1962) "Drinking Water Standards" as a guide for defining the limitations placed on stream use by mine drainage (table 4 ), it is apparent that mine drainage has seriously affected the utility of many streams in the region for domestic or municipal supply. Sampling sites where water-quality parameters exceeded recommended drinking water standards are shown in plate 1. Water quality at nearly 200 sites in the region did not meet recommended water standards. Table 5 describes the effects of mine-drainage index solutes on the potential use of these waters for municipal supplies. A comparison of data in table 4 with chemical-quality data in table 6 also suggests that several streams will not meet the water-quality criteria for many industrial uses of water.

Table 5.-Effect of mine drainage on the potential use of streams draining the coal region of Appalachia, May 1965

\begin{tabular}{|c|c|c|}
\hline \multirow{2}{*}{$\begin{array}{l}\text { Water-quality } \\
\text { parameter }\end{array}$} & \multicolumn{2}{|c|}{$\begin{array}{c}\text { Percentage of sample sites } \\
\text { where concentrations } \\
\text { exceeded drinking water } \\
\text { standards }\end{array}$} \\
\hline & $\begin{array}{l}\text { Sites unaf- } \\
\text { fected by } \\
\text { coal-mine } \\
\text { drainage }\end{array}$ & $\begin{array}{l}\text { Sites affected } \\
\text { by coal- } \\
\text { mine } \\
\text { drainage }\end{array}$ \\
\hline Iron_. & 6 & 35 \\
\hline Mangar & 34 & 83 \\
\hline Sulfate & 0 & 22 \\
\hline
\end{tabular}




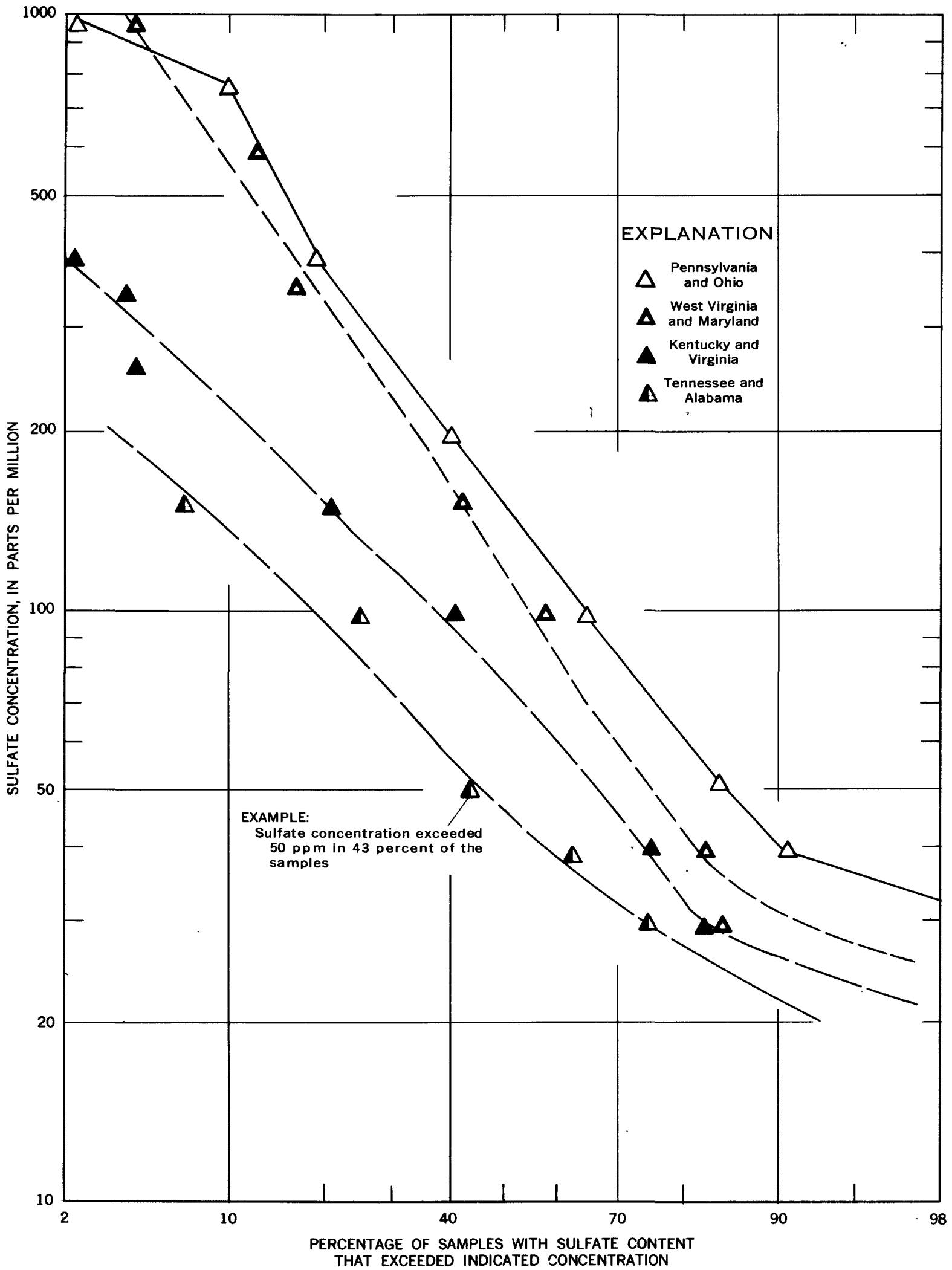

Figure 4. -Effect of coal-mine drainage on sulfate content from northern to southern Appalachia, May 1965. 


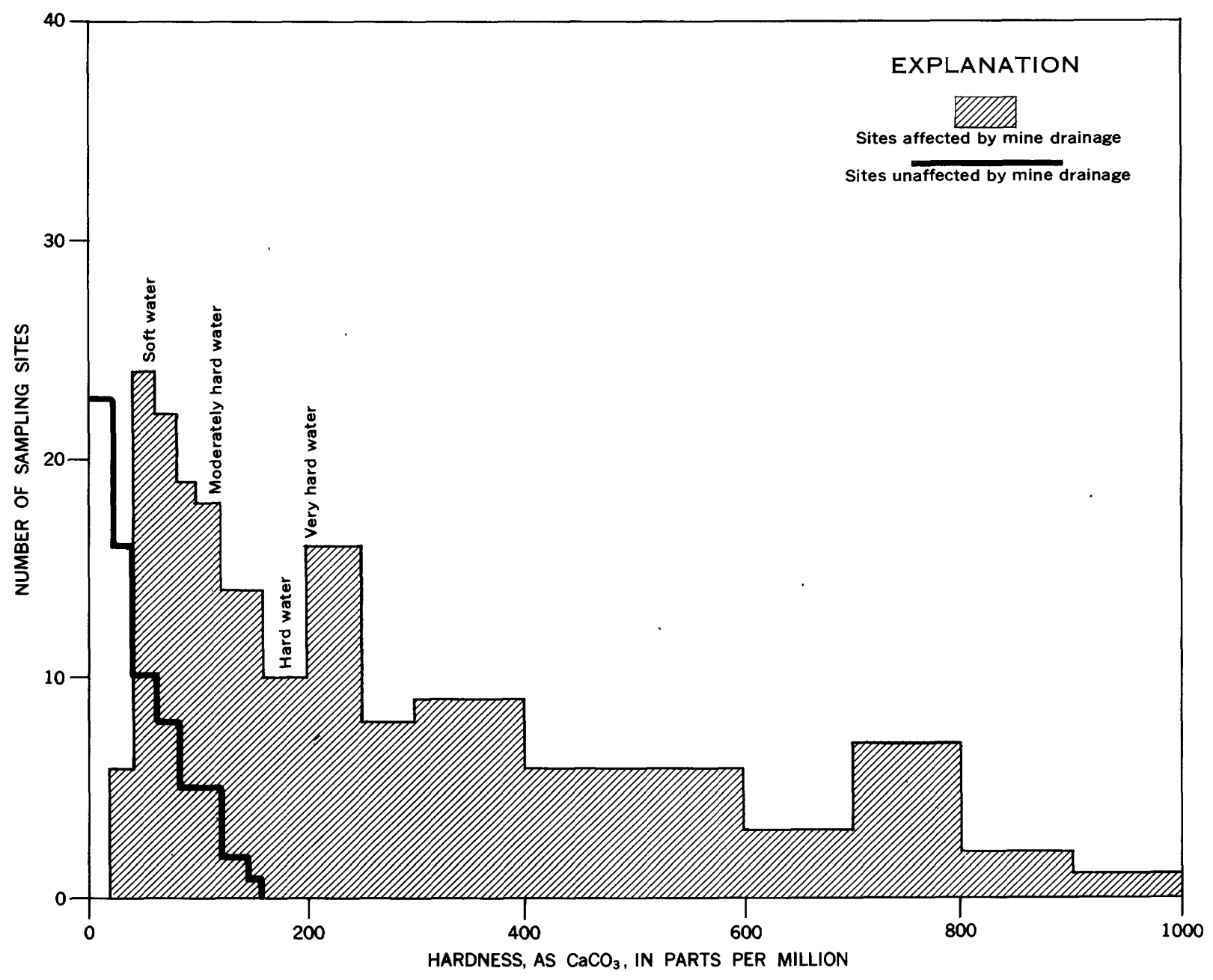

Figure 5. -Effect of mine drainage on the hardness of water, May 1965.

\section{NEUTRALIZATION OF ACID STREAMS}

The mixture of alkaline streams with mine-drainage waters eventually neutralizes all acid streams in Appalachia. Even in the badly polluted upper Ohio River basin, the added flow from the Allegheny River and other more alkaline downstream tributaries ultimately produces water of fair quality (fig. 6). Observed $\mathrm{pH}$ increases from less than 4.7 in the Monongahela River to approximately 7.0 in the Ohio River at Stratton, Ohio. There is also a gradual increase in the ratio of bicarbonate to sulfate between these two sites. Stream hardness continues to increase downstream, but a greater part of the hardness is carbonate hardness.

Thus, while the problem of stream pollution by mine drainage is particularly serious in headwater areas of Appalachia near active and abandoned mines, the alkaline contribu- tion of streams both in and out of the coal region measurably improves the quality of affected waters.

\section{CONCLUSIONS AND RECOMMENDATIONS}

The May 1965 field reconnaissance discloses that the water quality at 194 of 318 sampling sites was measurably influenced by mine drainage. Thirty sites contained water with free mineral acidity. Nearly all major acid streams in Appalachia were in the northern one-third of the region.

The natural alkalinity of streams within the coal region was generally low, usually less than $50 \mathrm{ppm}$. The reconnaissance discloses that most of these streams are relatively incapable of neutralizing large quantities of acid mine water. However, high bicarbonate content was fairly typical of many streams affected by mine drainage within a 

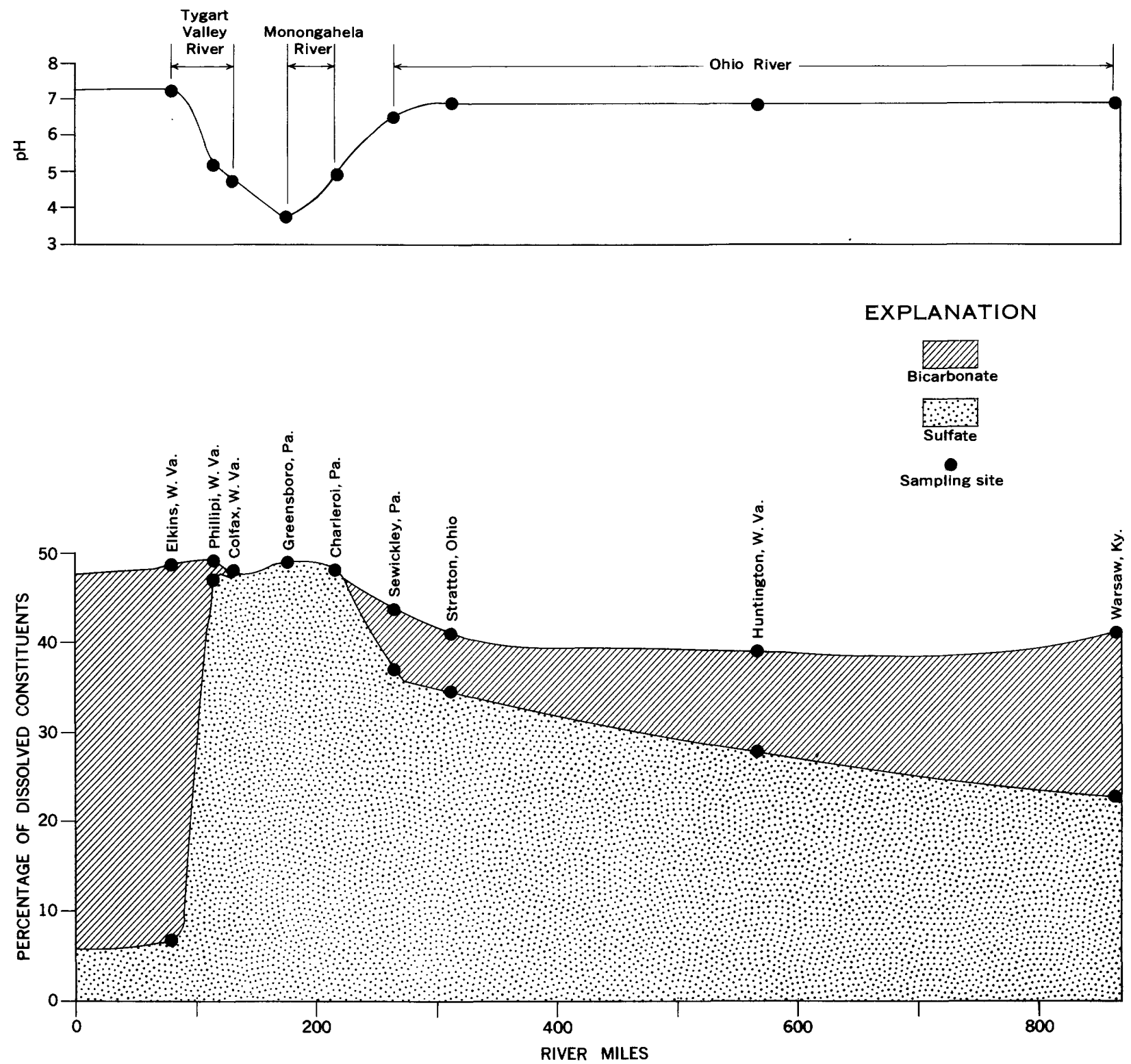

Figure 6. - Changes in the composition of a mine-polluted stream during neutralization, Ohio River basin, May 1965.

comparatively narrow area of the coal region from eastern Ohio to western Virginia. Apparently, there is significant neutralization of mine water in this area either by alkaline water in the mines, or by small unaffected headwater tributaries.

Analysis of sulfate content of streams affected by mine drainage indicates that less sulfate occurs in streams in the south half of the region. These data also provide further evidence that less acid water is produced per square mile in the south than in the north, probably because of less intense mining.
More serious water-quality damage from coal-mine drainage occurs in: the West Branch Susquehanna River, Kiskiminetas River, and Casselman River basins in Pennsylvania; North Branch Potomac River basin in Maryland; Monongahela River basin in Pennsylvania and West Virginia; and Raccoon Creek basin in Ohio.

Regardless of size or degree of acidity, all streams affected by mine drainage are ultimately neutralized by the inflow of alkaline water. 
Future regional studies should be designed to provide data for better definition of: (1) the significance of mine drainage upon stream quality during low-flow conditions, (2) types of hydrologic environment that produce sudden flushes of mine water to streams which normally contain relatively little mine water, and (3) the geologic and hydrologic factors contributing to high alkalinity of affected streams within isolated parts of the region.

\section{REFERENCES}

American Public Health Association, 1960, Standard methods for the examination of water and wastewater: New York, Am. Public Health Assoc., p. 42-43.

Barnes, Ivan, and Clarke, F. E., 1964, Geochemistry of ground water in mine drainage problems: U.S. Geol. Survey Prof. Paper 473-A, p. A1-A6.

Braley, S. A., 1954, Summary report of Commonwealth of Pennsylvania, (Department of Health) Industrial Fellowship Nos. 1 to 7 incl. (From August 20, 1946, through December 31, 1953): Mellon Inst. of Industrial Research, $279 \mathrm{p}$.

California Water Quality Control Board, 1963, Water quality criteria: Calif. Water Control Board Pub. 3-A, 548 p.

Kinney, E. C., 1964, Extent of acid mine pollution in the United States affecting fish and wildlife: U.S. Fish and Wildlife Service Circ. 191, 27 p.

Krickovic, Stephen, 1965, U.S. Bureau of Mines acid mine drainage control program and joint Interior-HEW Departments acid mine drainage control program, in Papers presented before symposium on acid mine drainage research, Mellon Institute, May 20-21, 1965, Pittsburgh, Pennsylvania: p. 111-126.

Mackenthun, K. M., 1965, Nitrogen and phosphorus in water: U.S. Public Health Service Pub. 1305, $111 \mathrm{p}$.

Rainwater, F. H., 1962, Stream composition of the conterminous United States: U.S. Geol. Survey Hydrol. Inv. Atlas HA 61 .

Rainwater, F. H., and Thatcher, L. L., 1960, Methods for collection and analysis of water samples: U.S. Geol. Survey Water-Supply Paper 1454, p. 87-92.
Schneider, W. J., and others, 1965, Water resources of the Appalachian region, Pennsylvania to Alabama: U.S. Geol. Survey Hydrol. Inv. Atlas HA-198.

Stumm, Werner, 1965, Oxygenation of ferrous iron properties of aqueous iron as related to mine drainage pollution, in Papers presented before symposium on acid mine drainage research, Mellon Institute, May 20-21, 1965, Pittsburgh, Pennsylvania: p. 51-63.

Trumbull, James, 1960, Coal fields of the United States: U.S. Geol. Survey Mineral Inv. Resources Map MR-2651, sheet 1.

U.S. Army Corps of Engineers, 1962, Blanchard Reservoir, West Branch Susquehanna River, Pennsylvania, in Design memorandum 1, Hydrology and hydraulic analysis: U.S. Army Corps of Engineers.

U.S. Bureau of Mines, 1964, 1963 minerals yearbook. U.S. Bur. Mines, v. 2 Fuels, 533 p.

U.S. Congress, 1944, Ohio River pollution control-Report of the United States Public Health Service: U.S. 78th Cong., 1st sess., House Doc. 266.

1962, Acid mine drainage-A report prepared for the Committee on Public Works, House of Representatives, by Division of Water Supply and Pollution Control, Public Health Service, U.S. Department of Health, Education, and Welfare: U.S. 87th Cong., 2d sess., House Comm. Print 18.

U.S. Department of the Interior, 1965, Proposed outline of report required on strip and surface mining in the United States as authorized under Public Law 89-4, section 205 of the Appalachian Regional Development Act of 1965: U.S. Dept. Interior, Office of Assistant Secretary-Mineral Resources, p. $43-45$.

U.S. Public Health Service, 1962, Drinking water standards: U.S. Public Health Service Pub. 956, $61 \mathrm{p}$.

Whetstone, G. W., 1963, Statement of water resources investigations in the Monongahela River basin, in Conference in the matter of pollution of the Interstate waters of the Monongahela River and its tributaries: U.S. Dept. of Health, Education, and Welfare, Public Health Service, Conf. Proc., p. 31-147. 

BASIC DATA 


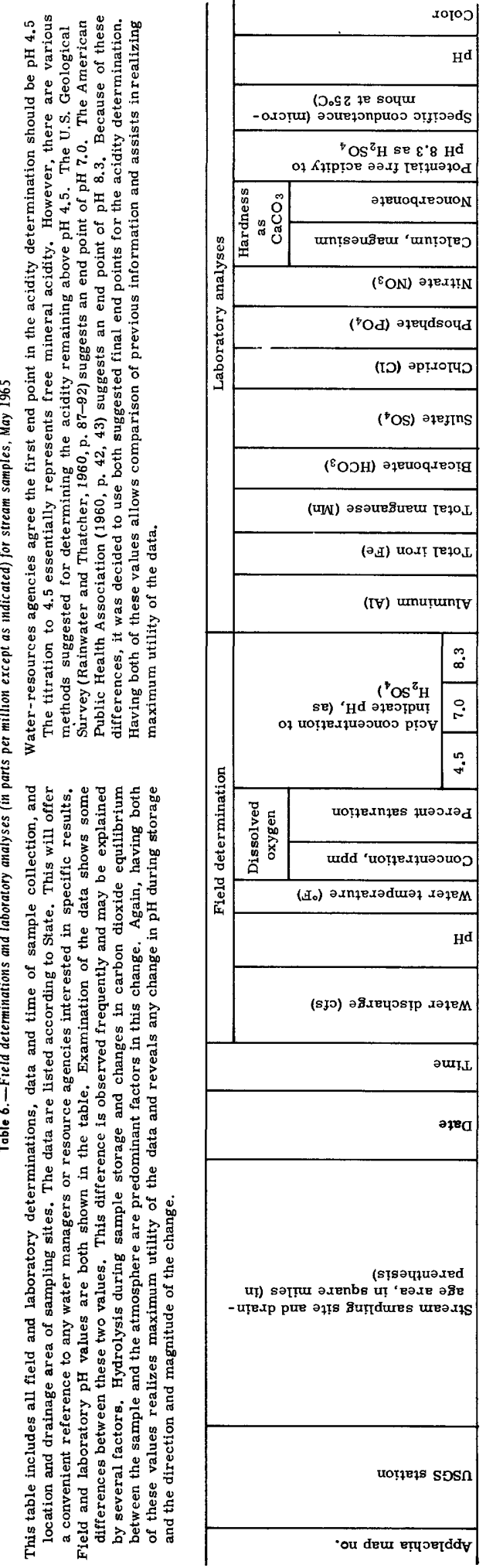

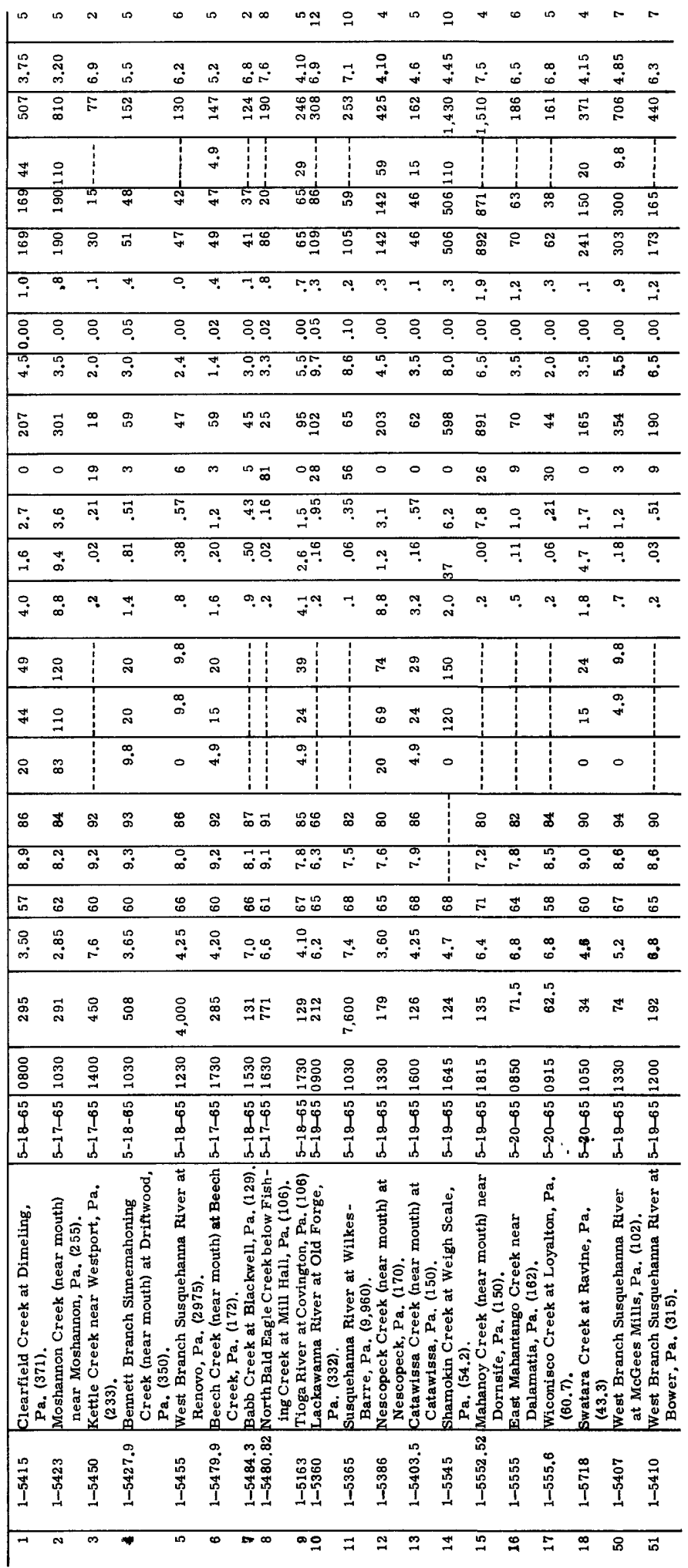




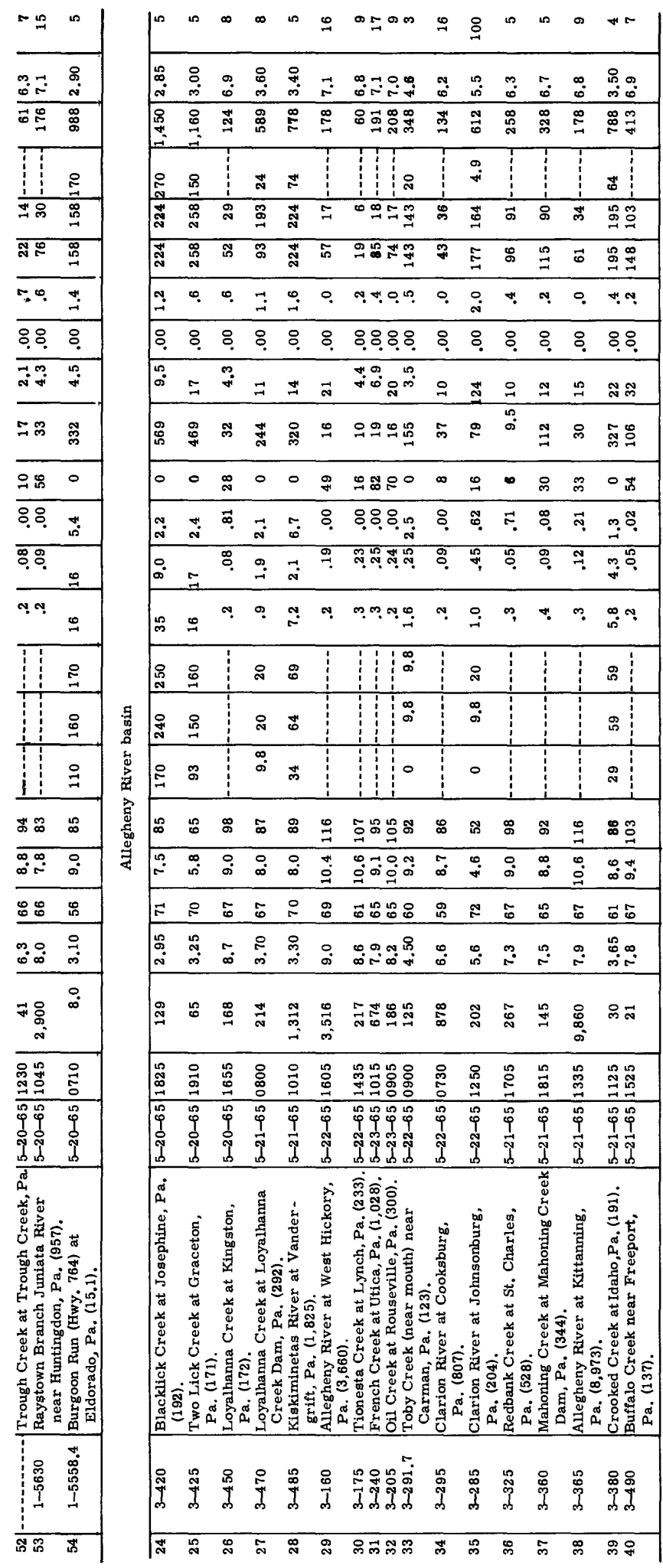

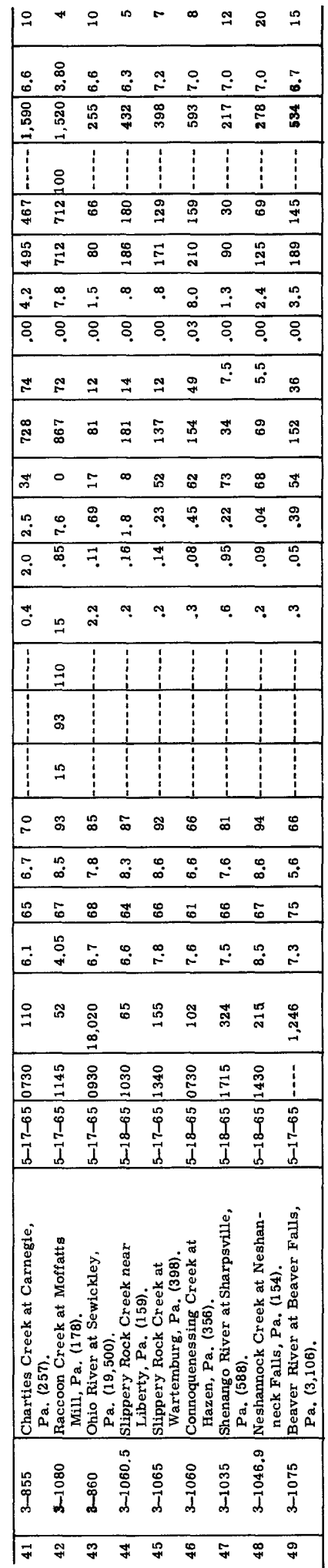

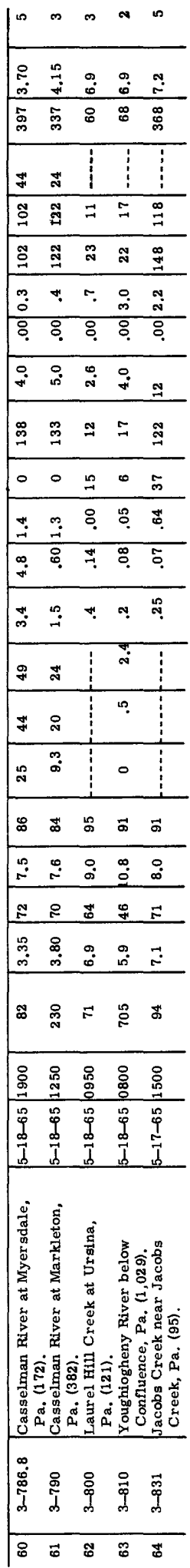




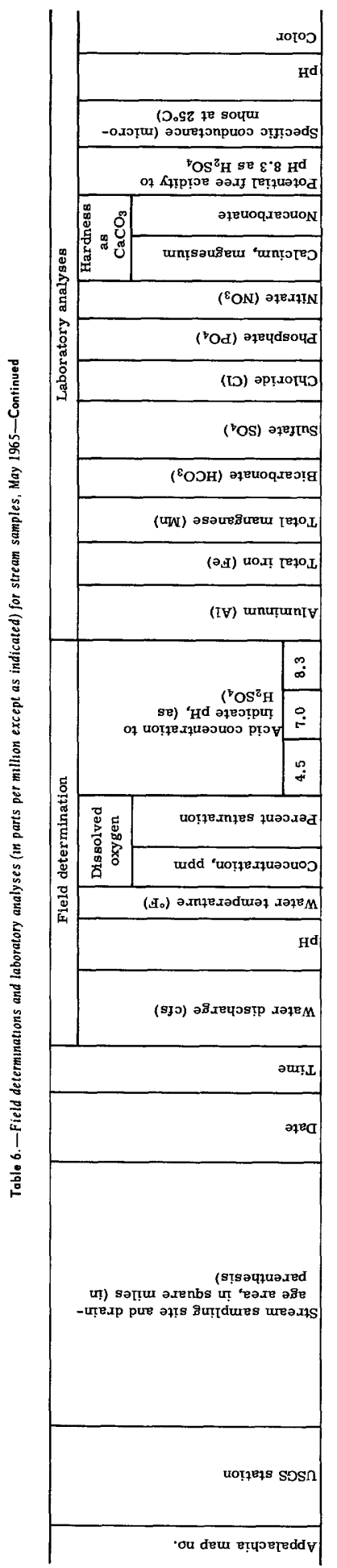

STREAM QUALITY IN APPALACHIA AS RELATED TO COAL-MINE DRAINAGE

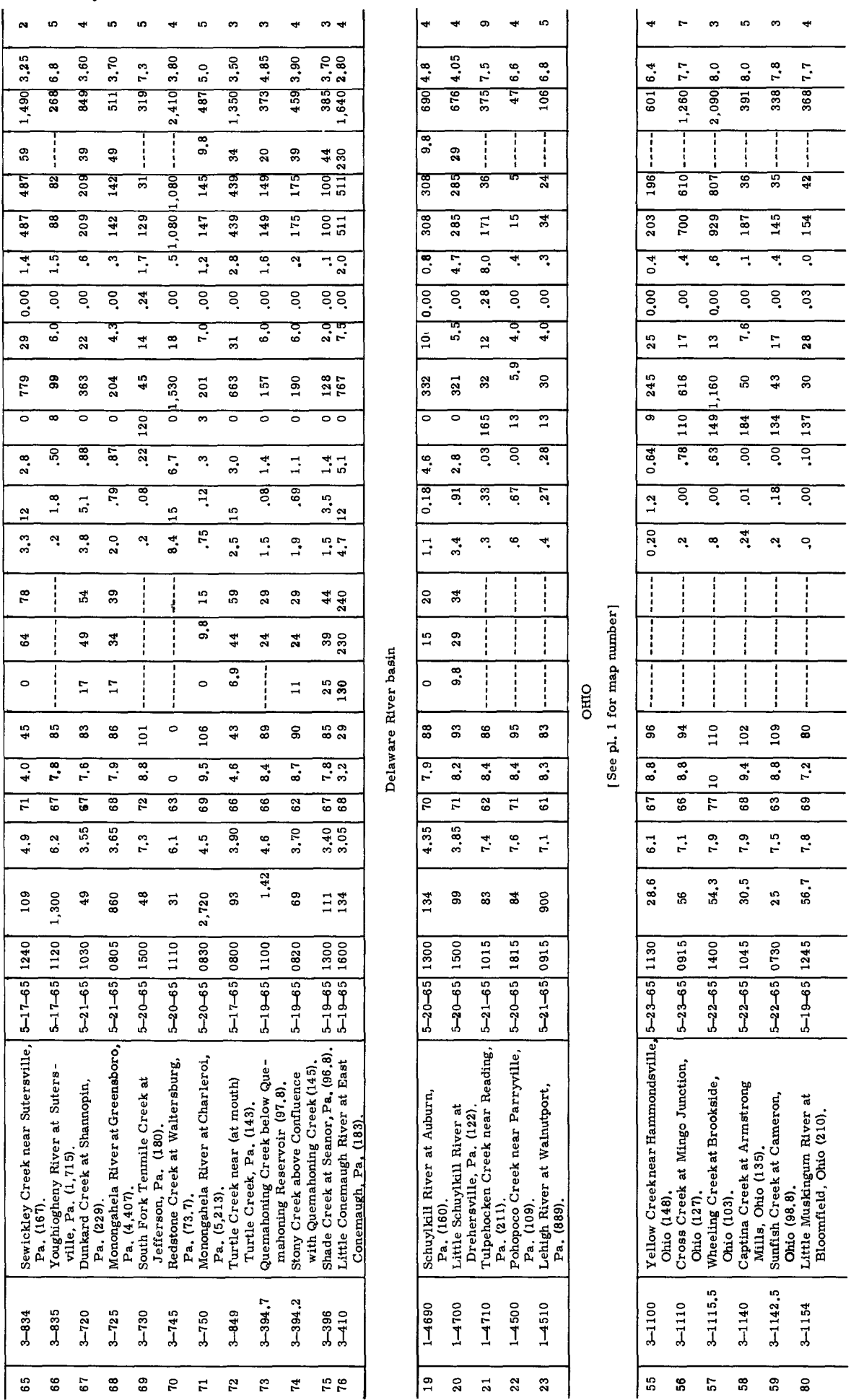




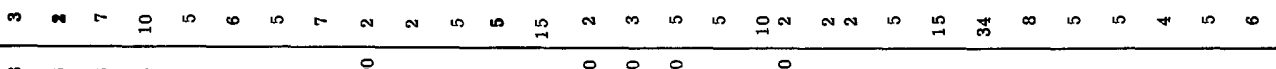

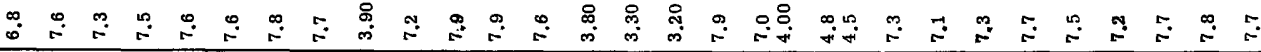
总 过

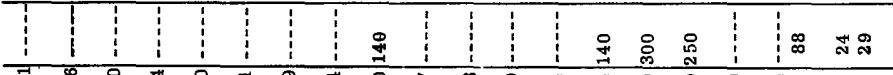

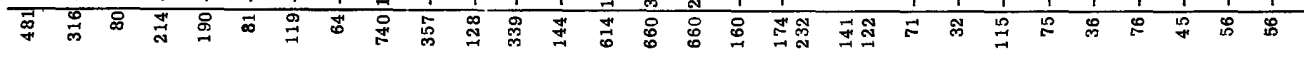

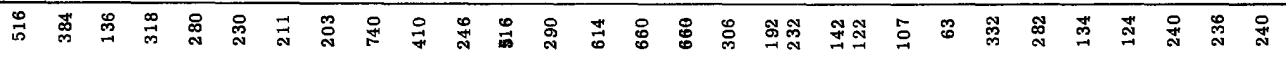
ฯ ฯ \& 웅 号 号 ホ

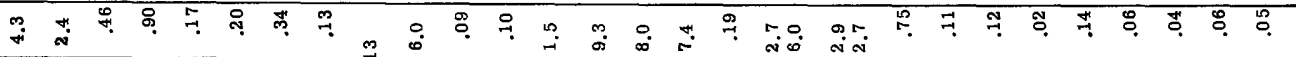
¥

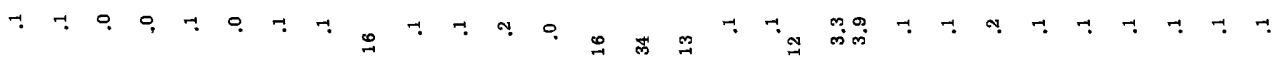

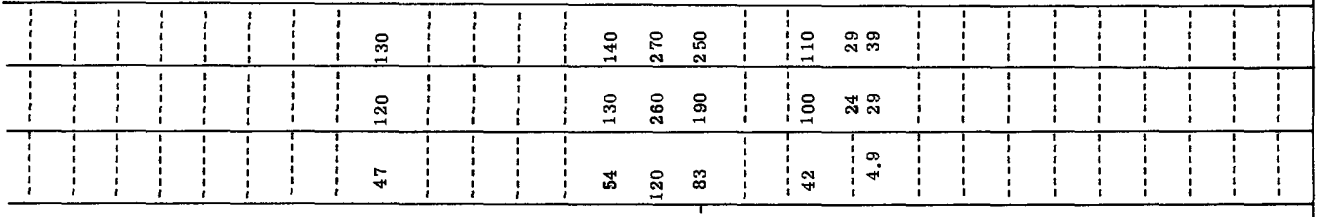
ஜ

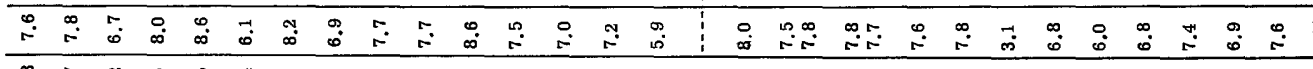
Ð ণै 官 号

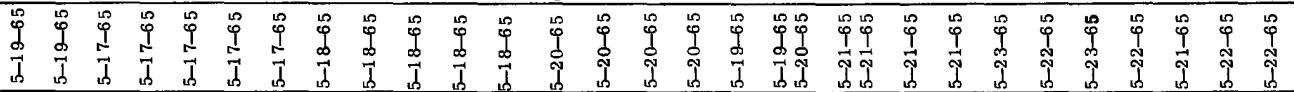

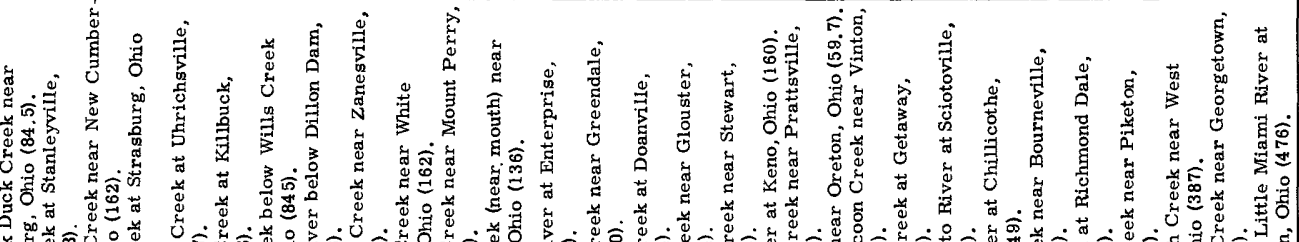

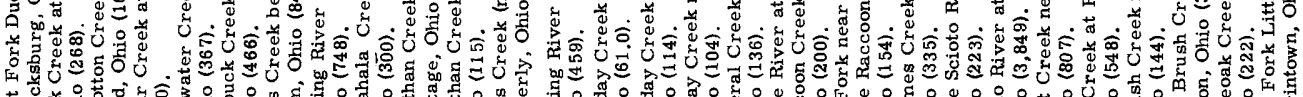

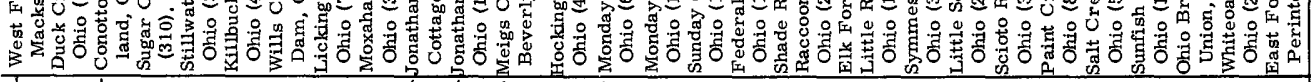

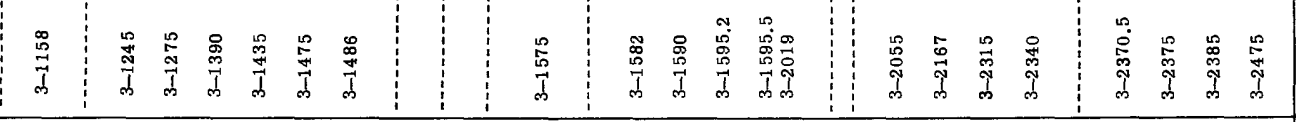

ద

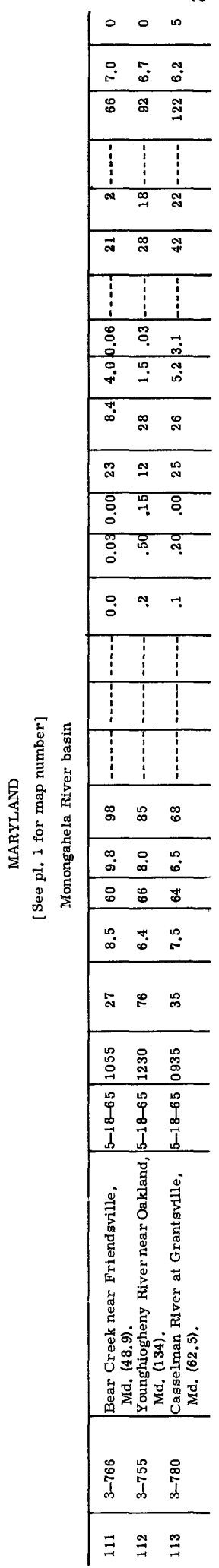


20

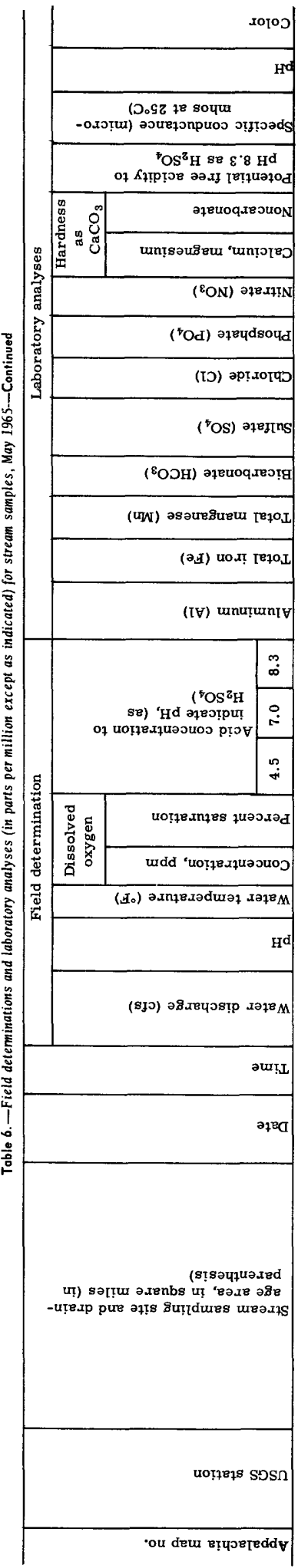

STREAM QUALITY IN APPALACHIA AS RELATED TO COAL-MINE DRAINAGE

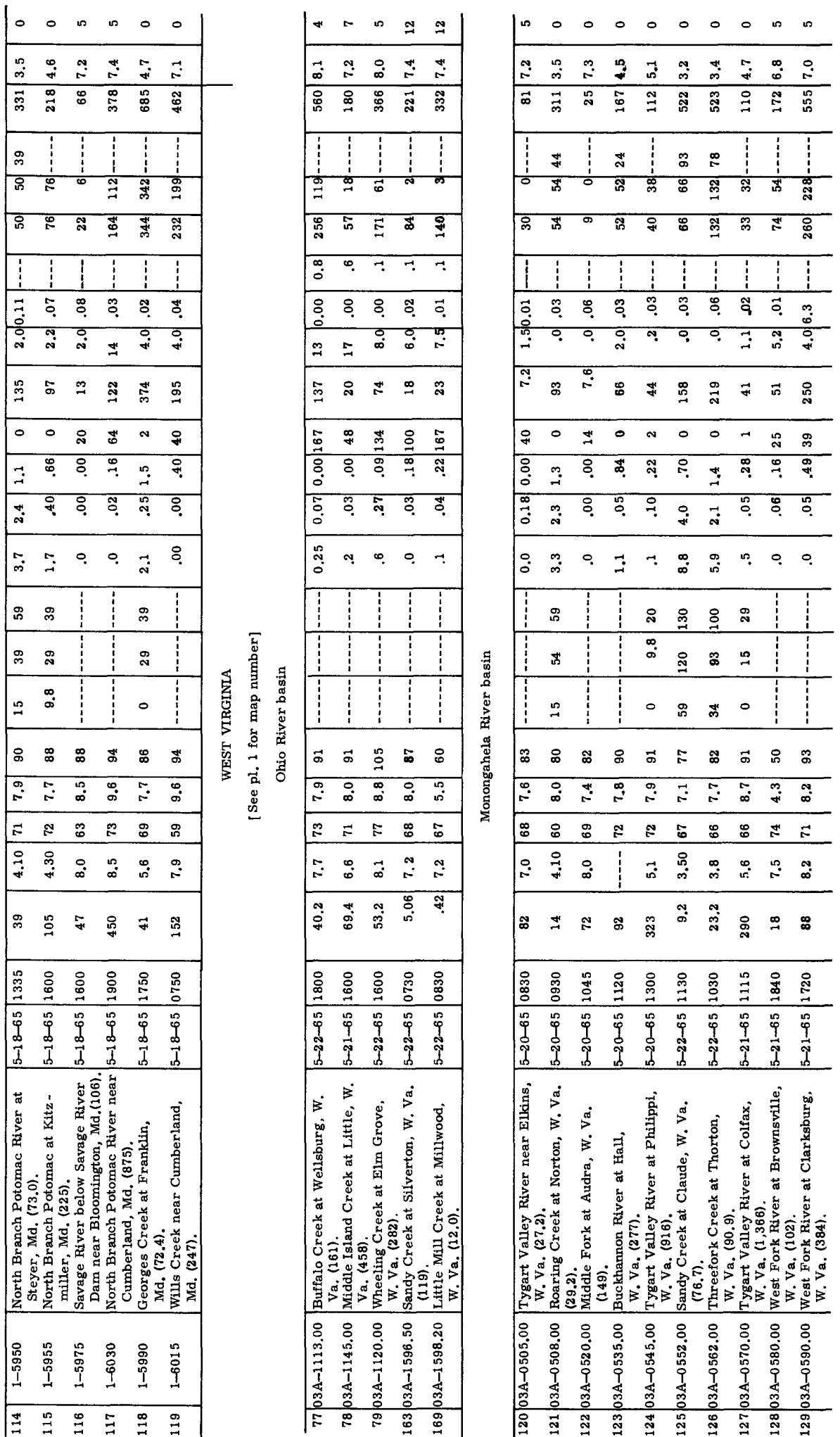




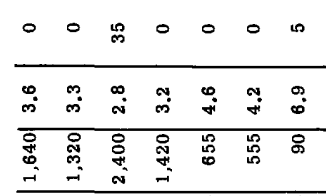

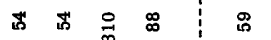

范 怘

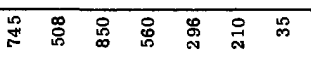

\begin{tabular}{l|l|l|l|l}
\hline 1 & 1 & 1 & 1 \\
\hline
\end{tabular}

๑.

कृ

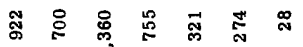

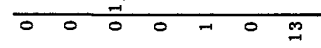

শั.

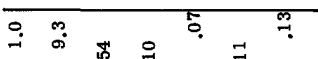

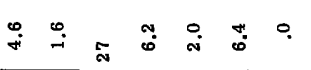

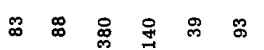

ஃ

ㅇ

๑

त्ञ

怘

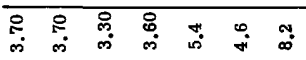

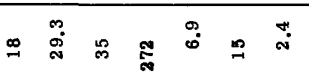

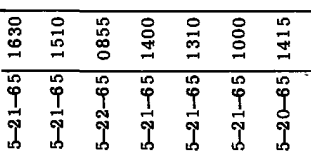

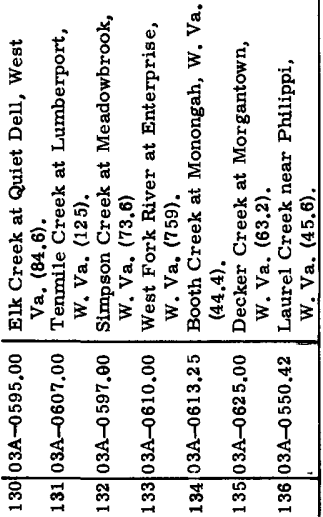

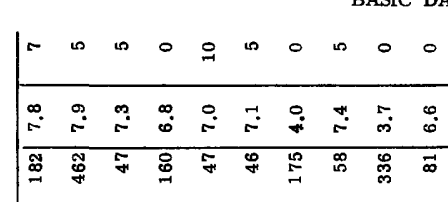

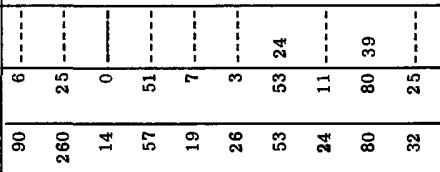

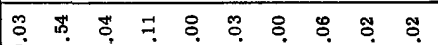

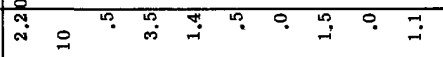

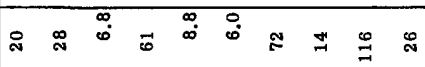

兽

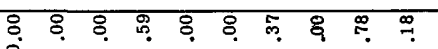

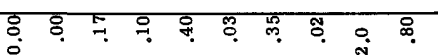

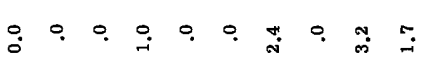

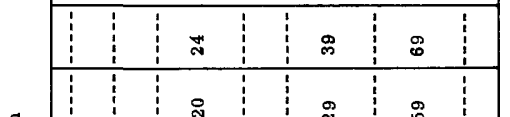

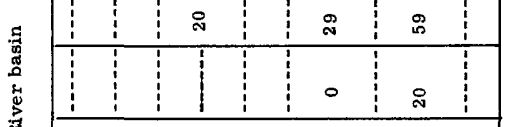

है:

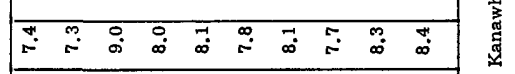

ग

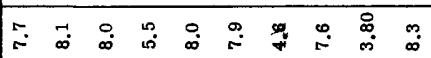

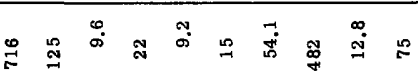

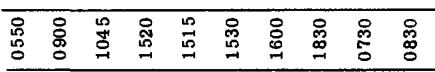

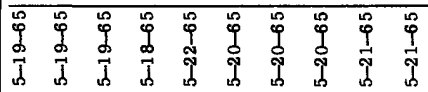

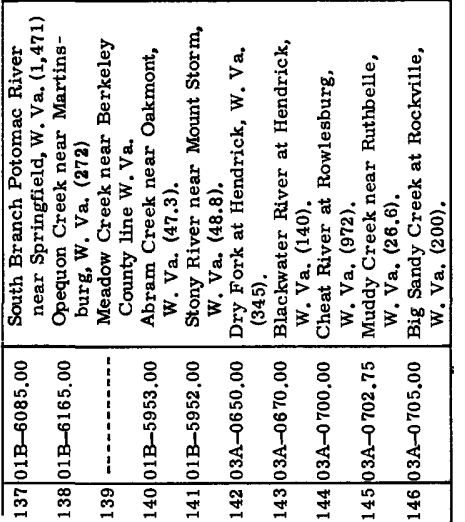

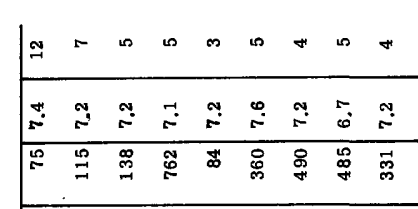

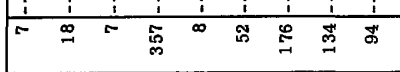

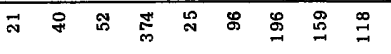

ֻุ

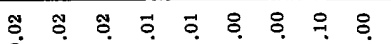

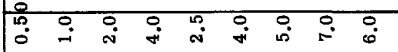

స

స ヘ

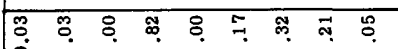

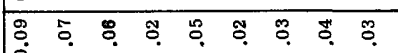

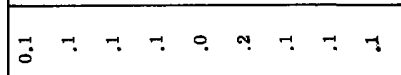

丞

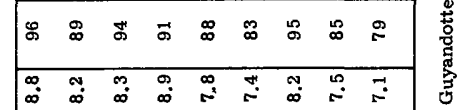

ธะค

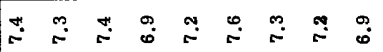

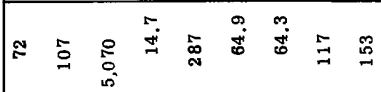

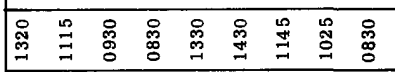

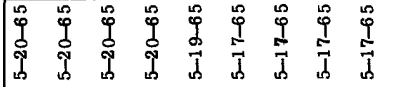

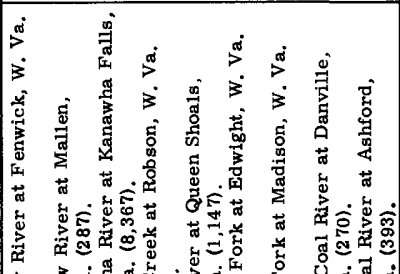

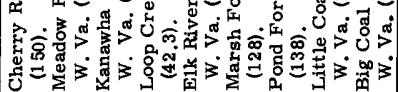

$8 \% 8 \% 8 \% 8$

䓌

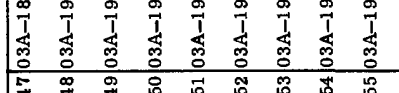

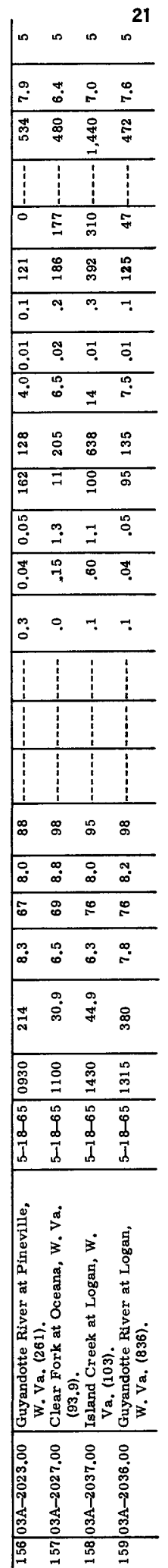




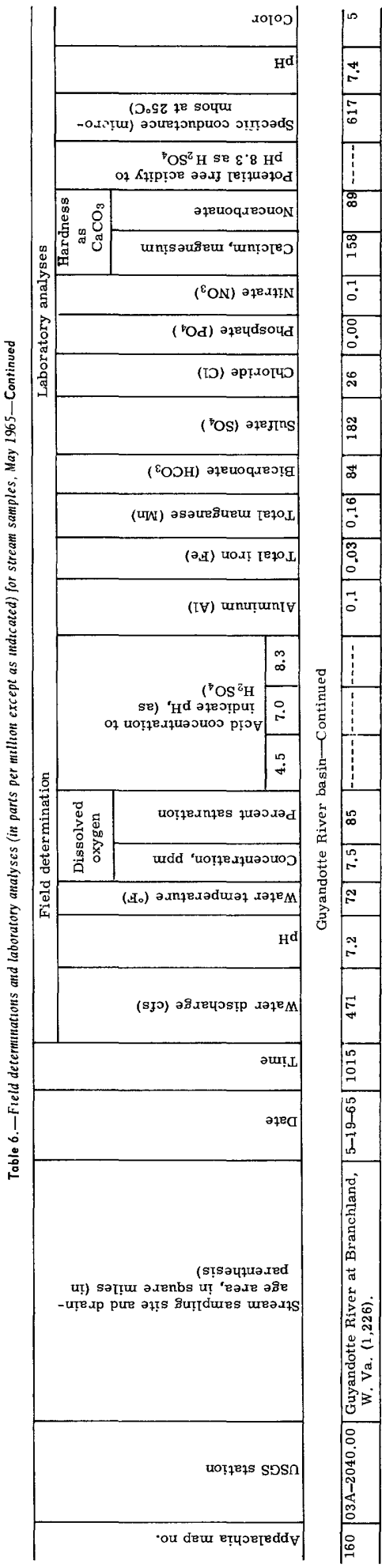

STREAM QUALITY IN APPALACHIA AS RELATED TO COAL-MINE DRAINAGE

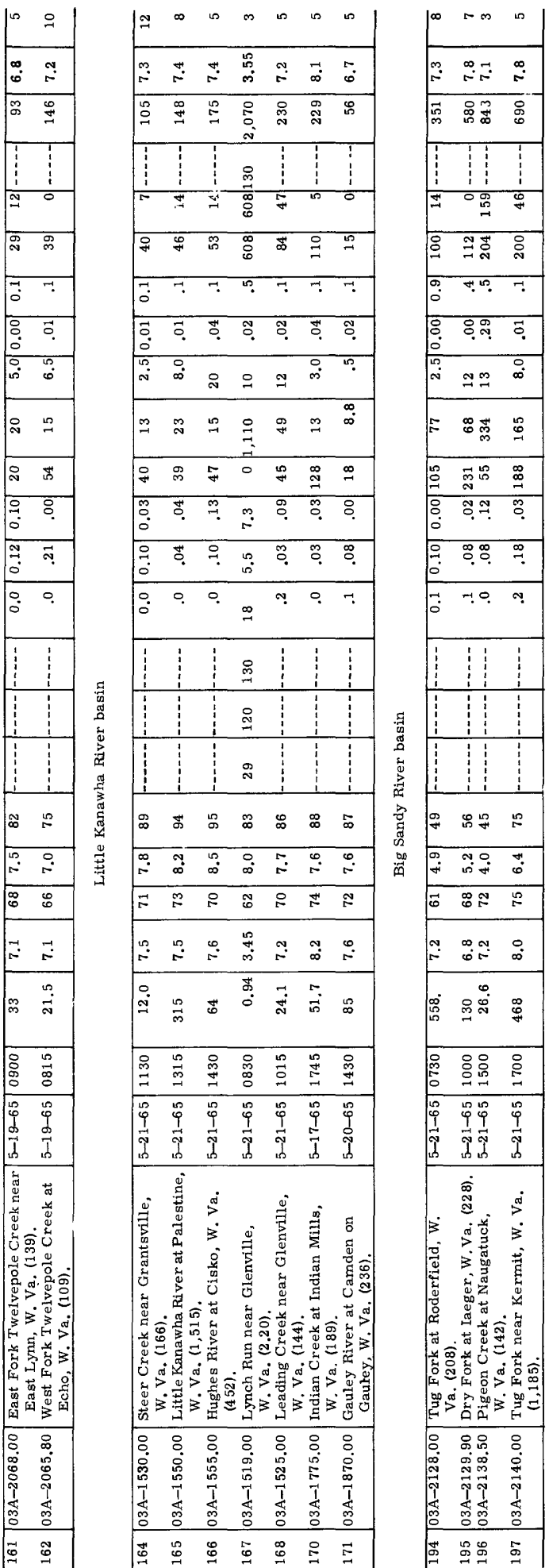

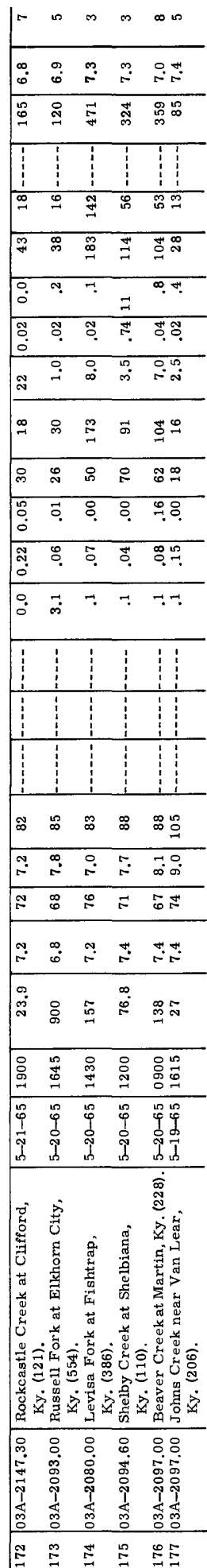


BASIC DATA

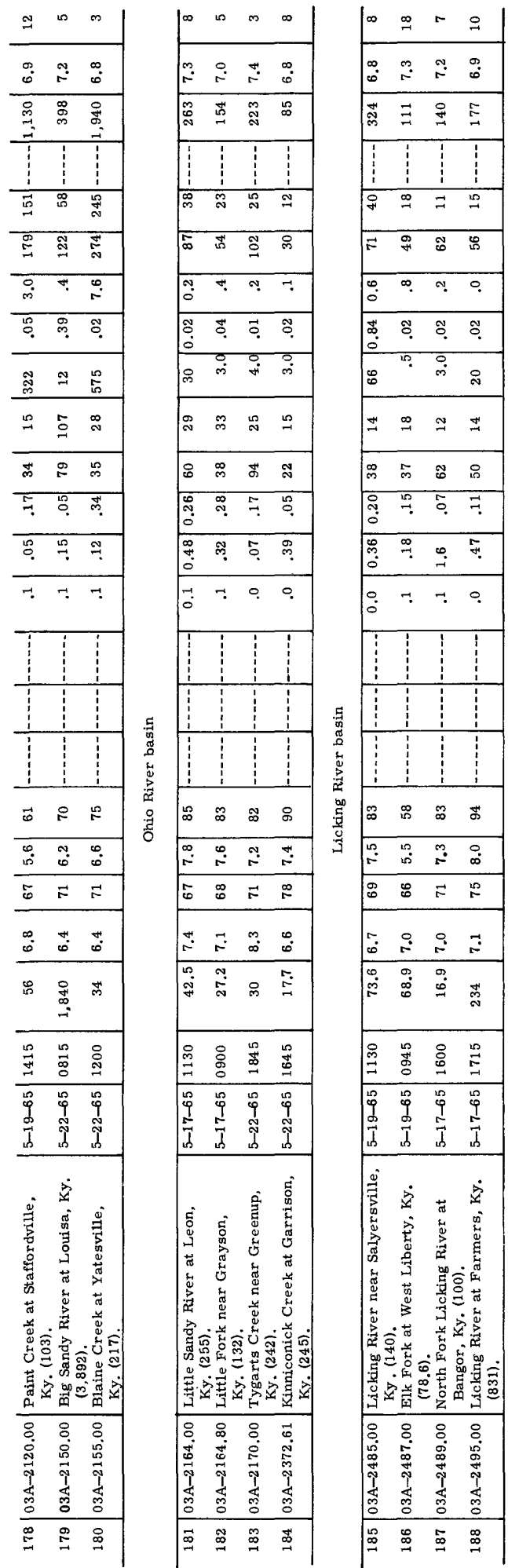

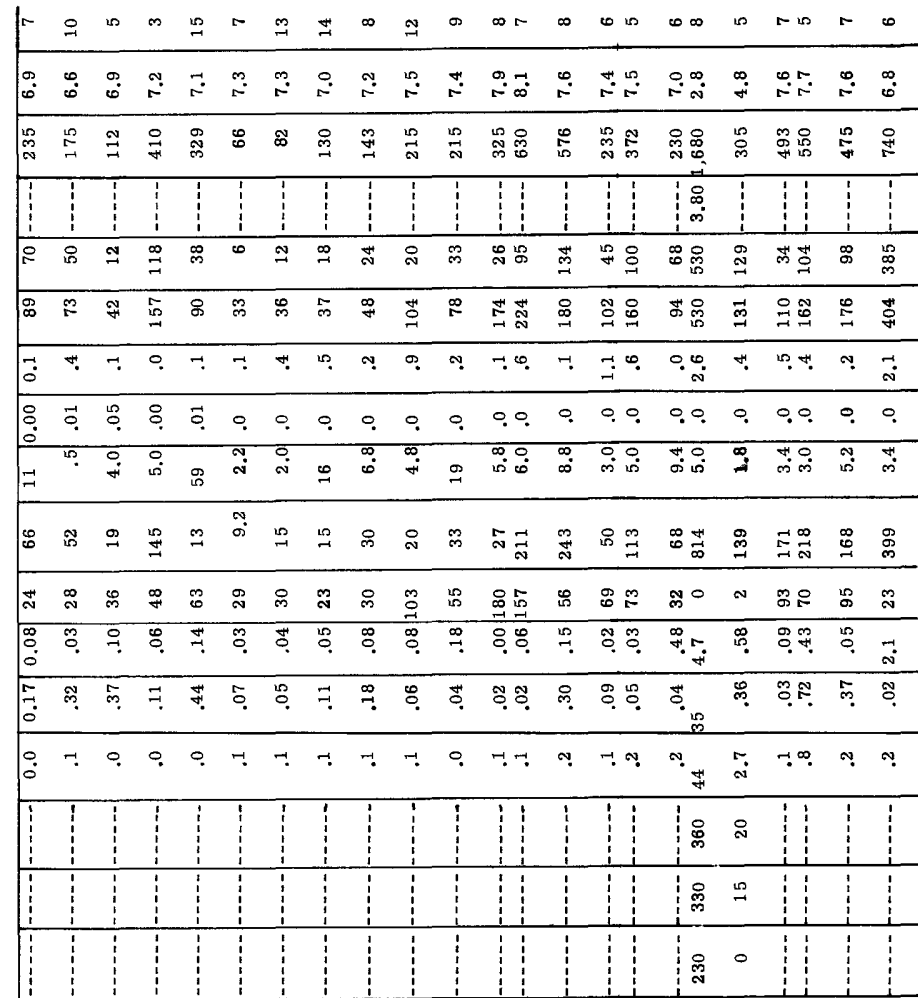

下

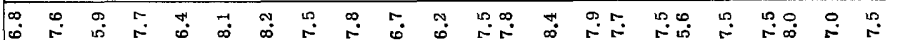

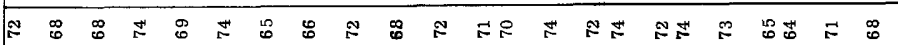

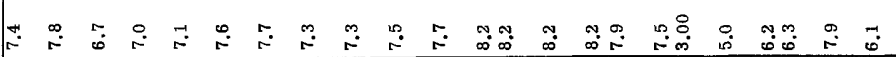

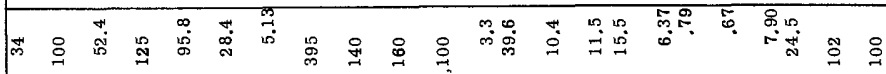

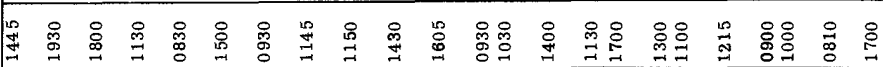
蕰

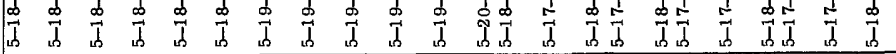

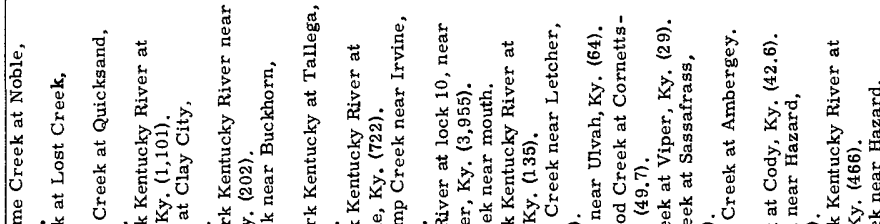

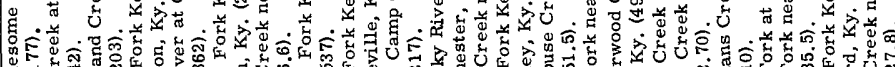

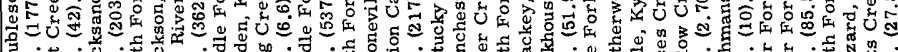

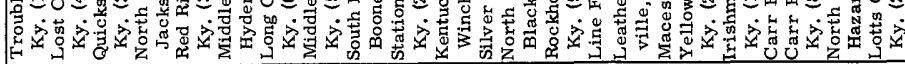
$\div: 8 \div 8 \div$

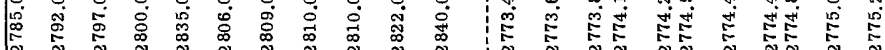

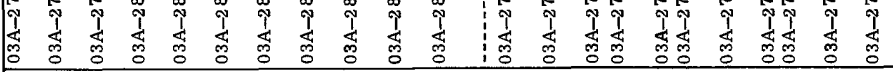

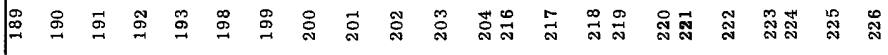




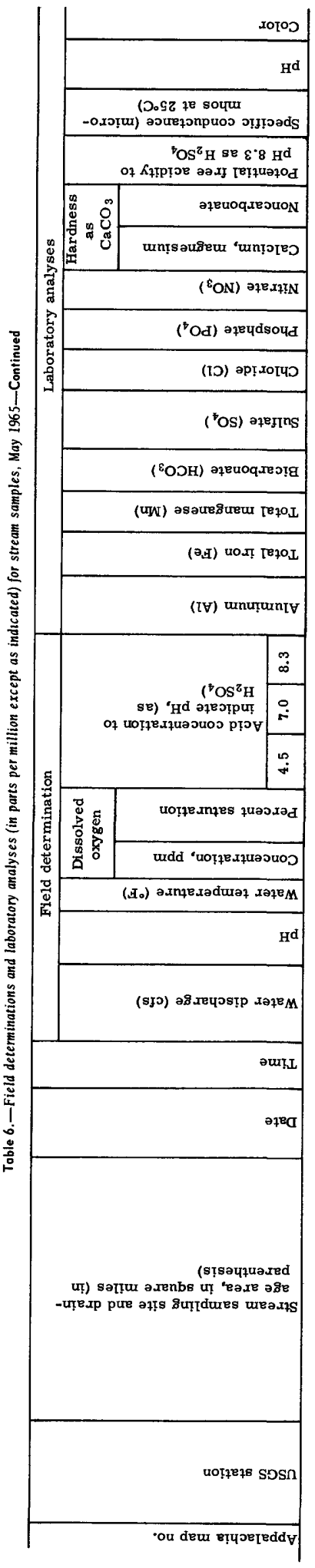

STREAM QUALITY IN APPALACHIA AS RELATED TO COAL-MINE DRAINAGE
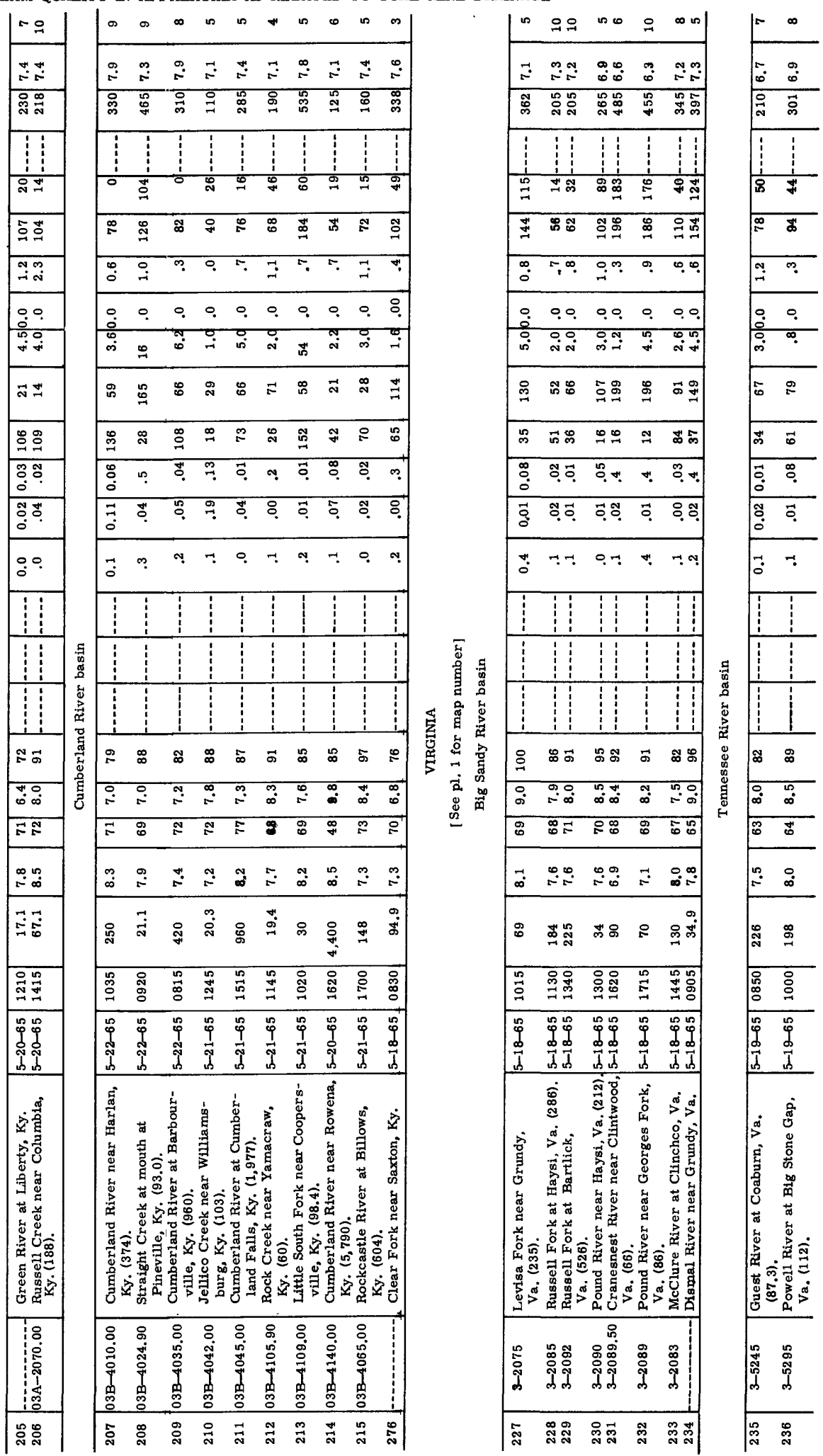


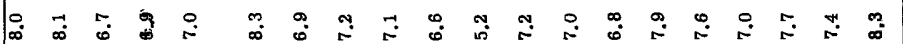
浆

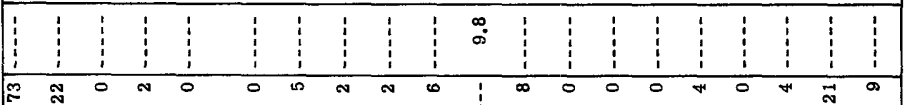

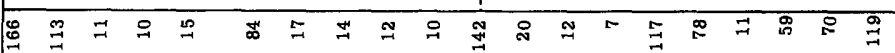

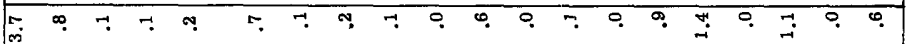
\% ८ ८ ८ ก ఇ 乎

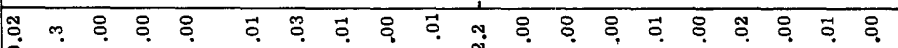
ֻ

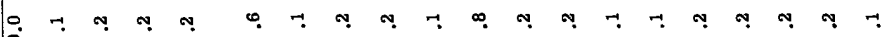
可施

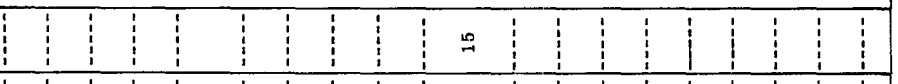

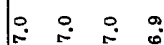

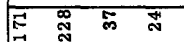

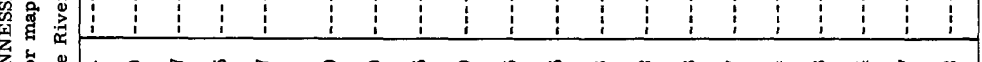

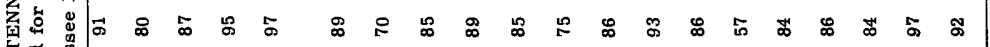
:

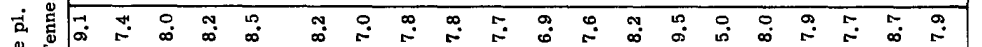
苟 范 吕

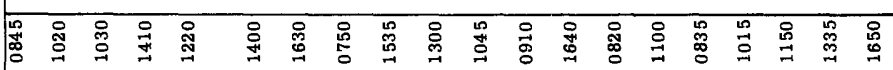

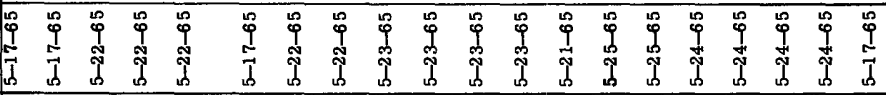
का

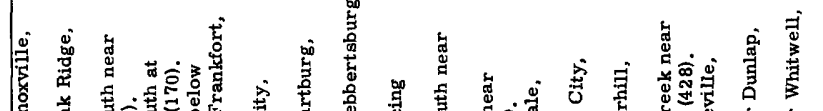

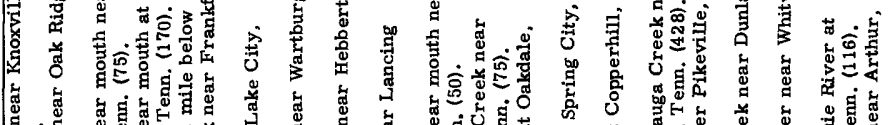

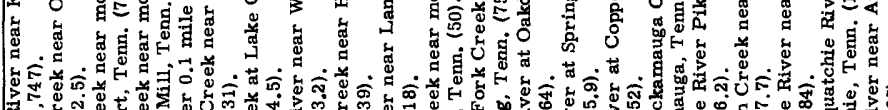

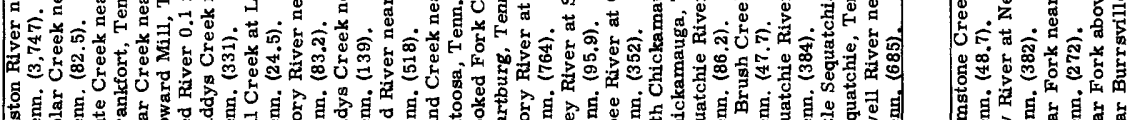

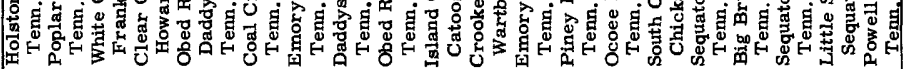

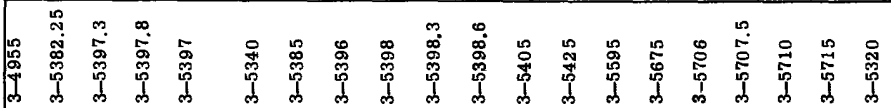

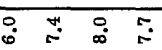

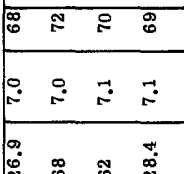
萧

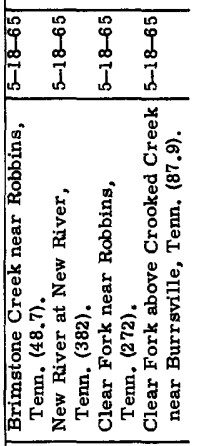

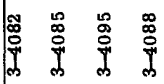

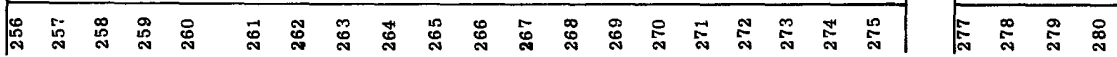




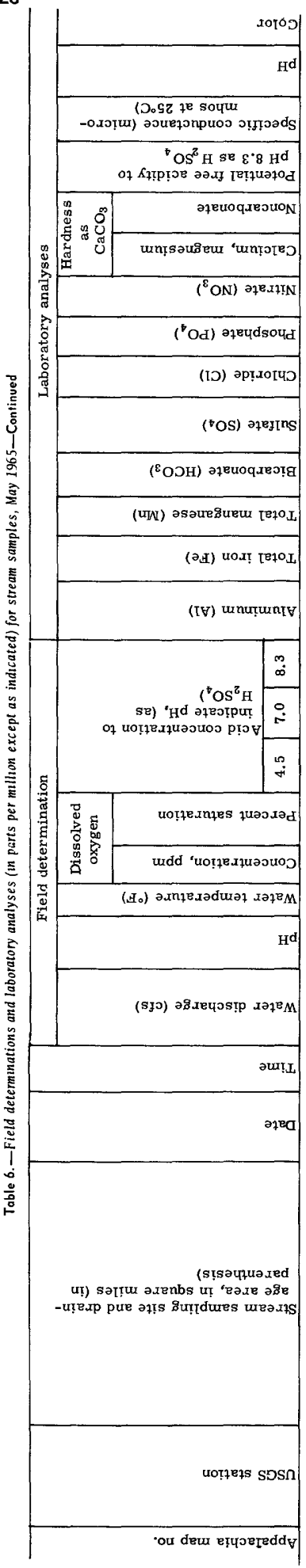

STREAM QUALITY IN APPALACHIA AS RELATED TO COAL-MINE DRAINAGE

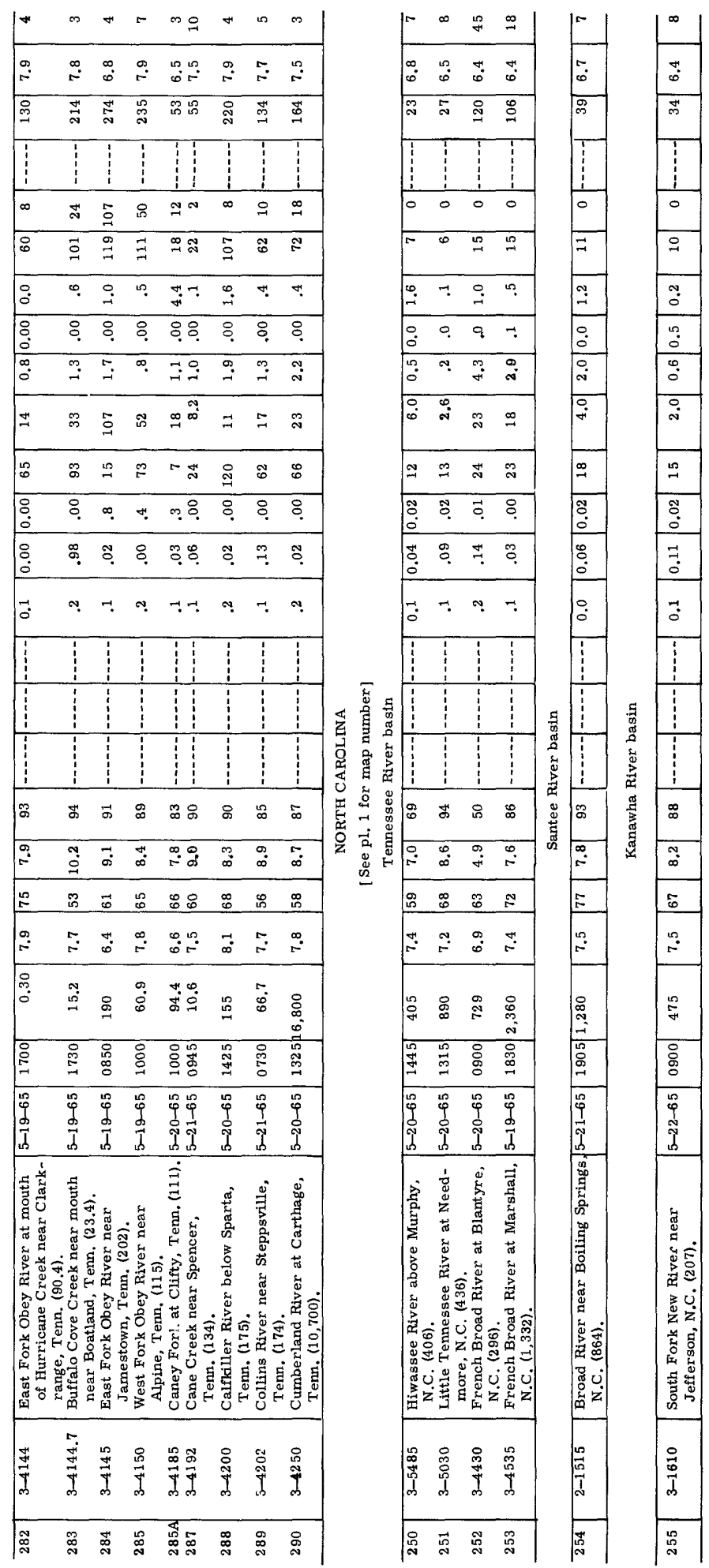

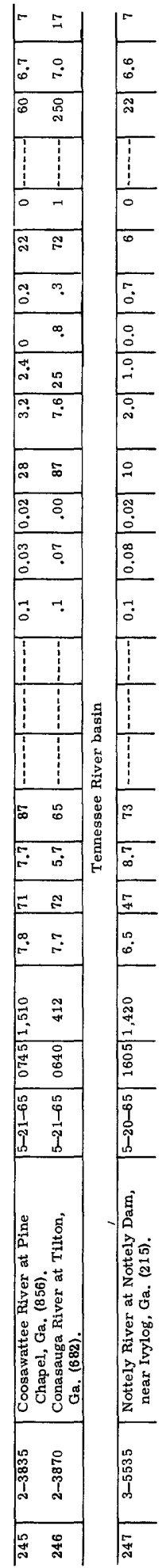




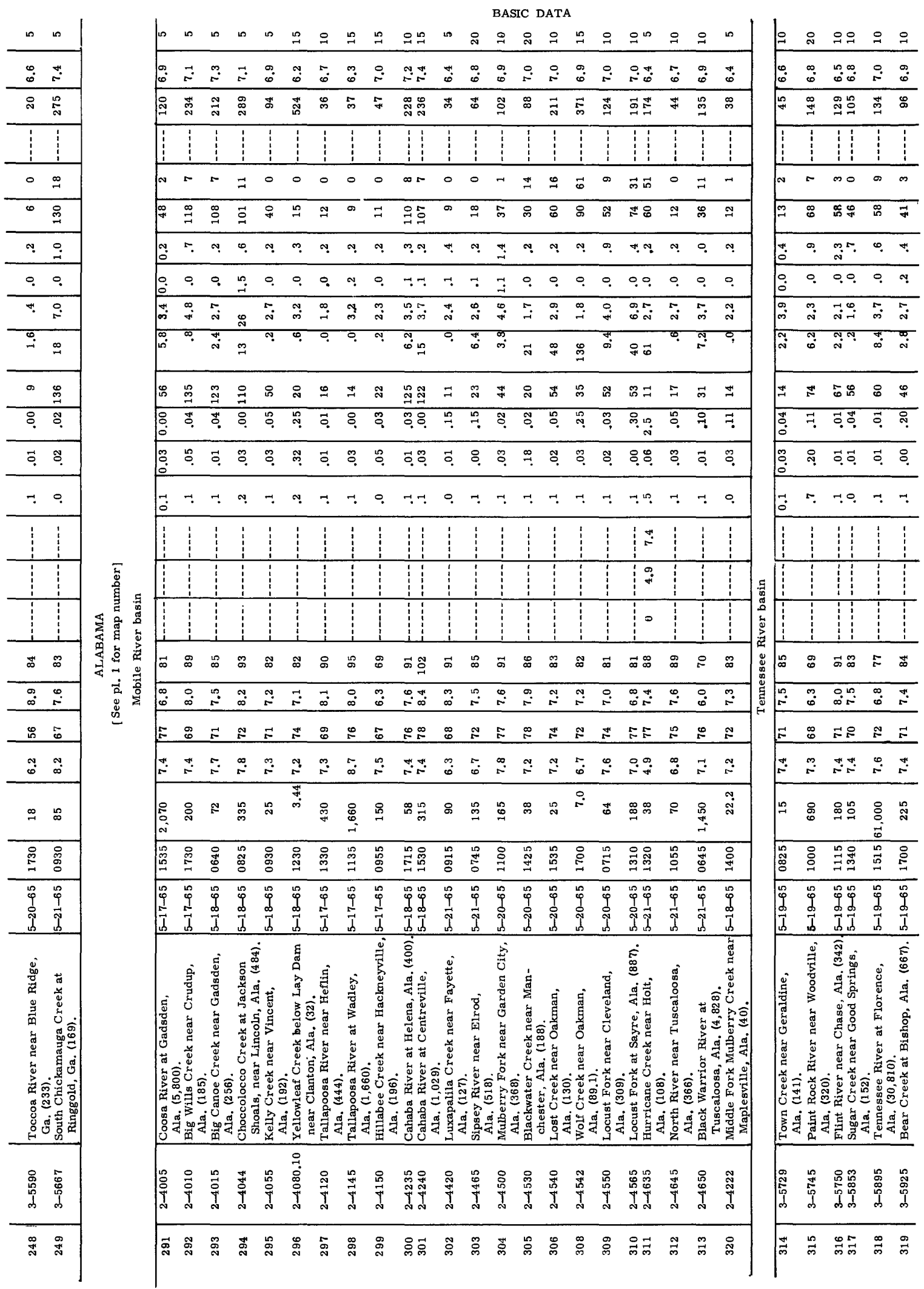

